\title{
Do Disadvantaged Young Adults Benefit Less from Social Investment? Studying Matthew Effects in Activation Measures
}

\author{
VeronikaJ. Knize \\ Institute for Employment Research (IAB), Research Department Basic \\ Income Support and Activation, Nuremberg, Germany \\ veronika.knize@iab.de
}

\author{
Markus Wolf \\ Institute for Employment Research (IAB), Research Department Basic \\ Income Support and Activation, Nuremberg, Germany \\ Corresponding author \\ markus.wolf2@iab.de

\section{Cordula Zabel} \\ Institute for Employment Research (IAB), Research Department Basic \\ Income Support and Activation, Nuremberg, Germany \\ cordula.zabel@iab.de
}

\begin{abstract}
In Germany, social investment can be crucial for disadvantaged young adults, as intergenerational mobility is low and credentials are decisive for employment. However, the literature on policy implementation calls attention to 'Matthew effects', by which the most disadvantaged often have the least access to social investment. We contribute to ongoing research on Matthew effects by examining whether the worst-off among young German welfare recipients are assigned to active labour market policy measures that are more advantageous or less advantageous. Findings for a register sample of $20-22$ year olds in 2014 support hypotheses that those with the lowest education and employment experience participate less often in the most advantageous measures; particularly in firm-based upskilling and employment assistance, and more often in measures that proved to be not as beneficial, such as workfare programmes. On a positive note, welfare experience during adolescence as an indicator of low socio-economic status in the family of origin does not additionally affect access to social investment policy measures.
\end{abstract}




\section{Keywords}

activation - active labour market policy - Matthew effects - social investment - youth unemployment - welfare receipt

\section{Introduction}

Over the past two decades, Europe has been developing policy measures to advance equal opportunities among young people, and this has not been without challenges. With the introduction of the White Paper of the European Commission, the European Union committed to taking more account of young people in the context of social policies with the goals of increasing employment and tackling poverty, as well as reducing social exclusion among these people. Nevertheless, the 2008 financial crisis hit young people hardest with dramatically elevated unemployment rates and an increasingly precarious labour market (Schoon \& Bynner, 2019). In response, academia and institutions called for attention to the high social and economic costs arising from substantial shares of people 'not in education, employment or training' (NEET). Particularly since then, the EU and member states have adjusted their strategies to overcome new challenges in reducing inequalities and long-term interruptions from participating in the labour market, education or training (EC, 2013; Eurofound, 2014, 2017; Higgins, 2018). The European Commission's reforms stressed modernising welfare policies towards inclusive and sustainable growth amid the youth employment crisis. In short, new policies imply strengthening human capital of young adults with a view to enabling them to sustainably (re)integrate into the labour market (EC, 2012, 2013).

In a European context of high youth disengagement from the labour market, Germany appears to find itself among the 'better-off' countries. Young adults in Germany have enjoyed relatively low shares of NEET since the financial crisis. Smoother school-to-work transitions based on an employment-centred training model with strong state assistance for becoming independent have contributed to this favourable work scenario (Eurofound, 2014; Walther, 2006).

Unfortunately, Germany has its own problems. Alongside a few other countries, differences in unemployment by educational level are the highest in Europe: less-educated 20-to-29-year-olds possess four or more times the unemployment risk of those with tertiary-level education, while the average in Europe is twice that in the age group $15^{-24}$ and three times that in the age group 
$25^{-29}$ (EC, 2018 p. 47). Eurofound (2017 p. 47) argued Germany is 'characterised by a 'hard core' of long-term unemployed young people, who typically have low educational attainment, a higher incidence of early school-leaving and a lack of vocational education'. In addition, the employment regime is highly regulated. 'Credentialism' is widespread; i.e. there is strong occupational closure due to an institutionalised high demand for educational certificates (Shavit \& Müller, 1998; Walther, 2006). A selective school system separates children at age 10-11 into schools with different durations and levels of difficulty. Within this system, children must prove their 'Leistungsfähigkeit' (high-performance abilities) from an early age (cf. Allmendinger, 1989). Solga (2002 p. 159) argued that, starting at school, less educated young people experience 'stigmatisation by negative selection', meaning they have decreasing access to other educational opportunities. With recurrent educational failure, the stigma acquired at an early age might later translate into self-exclusion from the educational system (Solga, 2004). Since employers trust the educational system, young people left behind end up facing many barriers to finding an apprenticeship or first labour market employment. To make things worse, it is well-known that discontinuous school-to-work transitions critically impair people's chances over the life course (e.g. Müller \& Gangl, 2003; Schoon \& Bynner, 2019).

In such a setting, young people from families with low socioeconomic status (SEs) might face great adversity. The role of parents is undeniable: their support to children (or lack thereof) is decisive for their development. Research has established that children from families with higher sEs do better than children from low sEs families in terms of education and employment (e.g. GrohSamberg \& Voges, 2014; Minello \& Blossfeld, 2017). Because receiving welfare benefits is a marker of low SES, young people from families on welfare might confront hardship in educational and employment settings not only while growing up, but also in the years thereafter.

The EU's strategy of social investment has been adjusted to fit within the German context (see Youth Strategy by BMFSJ, 2019 and Social Code), not least as an attempt to remedy inequalities resulting from educational failure and transmission of SEs. While several European initiatives have proved successful thus far (Eurofound, 2014, 2017), social investment measures targeted at the most disadvantaged do not always reach their target group, as has been documented e.g. in France, Italy and Romania. Scholars have drawn attention to a deficient delivery of active labour market policies (ALMP), prominently in cases wherein those who are worse off do not benefit much from social investment, which they define as 'Matthew effects' (Bonoli et al., 2017; Bonoli \& Liechti, 2018). We build on this discussion, understanding Matthew effects 
as an inequality mechanism by which initial advantage generates further advantage in terms of access to ALMP measures (Bonoli \& Liechti, 2018 p. 896). However, having access to policy measures does not necessarily lead to desirable results (e.g. Solga, 2004). Furthermore, the 'Hartz Iv' reforms intended for measures to be targeted towards specific groups of welfare recipients (Jacobi \& Kluve, 2007). Against this complex backdrop, we expand the discussion on ALMPs and inequality, debating whether measure selectivity, if any, indeed operates in the sense of Matthew effects.

Do disadvantaged youths on welfare face systematic negative selectivity in the allocation of ALMP programmes, being excluded from more promising measures while being assigned to less promising ones? To answer this question, we look at different facets of social inequality. We first consider achieved education and employment experience, with lower-level qualification certificates (or lack thereof) and less work experience being indicators for young people being worse off. Second, we differentiate young adults receiving welfare benefits by whether they had already been welfare recipients as adolescents in their parents' household. Due to intergenerational transmission of inequalities, those with prior welfare experience might be more disadvantaged than those without it. To address our research question, we apply logit models to a self-drawn sample of register data from the Statistical Department of the Federal Employment Agency (BA).

This paper's central interest lies in contributing to the literature by evaluating whether more disadvantaged youths benefit less from ALMP in terms of their access to these measures. Are differences between them and those better off ultimately intensified through delivery of ALMP? Thus far, only a few studies have focused on this topic. We enrich the ongoing research on Matthew effects (Bonoli et al., 2017; Bonoli \& Liechti, 2018; Auer \& Fossati, 2020) and ALMP selectivity (Osiander \& Fertig, 2015, Kruppe, 2009) by not only investigating the effects of education, but also of employment experience and previous benefit receipt during adolescence on access to ALMP measures in Germany. Because ALMP in Germany are in part products of international policy, our results are also relevant on a European level.

In the following, we first discuss ALMP measures and their potential effects on young adults and delineate previous empirical work on measure selectivity and Matthew effects. Then, we present our theoretical framework and background literature on intergenerational transmission of SES. Next, we present the data and method used, and explain the measures we analyse. Subsequently, we discuss our empirical findings. The final section presents our conclusions and discusses the implications of our findings. 


\section{Institutional Background: ALMP Programmes in Germany}

ALMP programmes have the aim of 'activating' welfare or unemployment benefit recipients - they either support or compel their educational or labour market integration. Measures are heterogeneous and diverse. Classifications of ALMP, such as Bonoli's (2010), are particularly valuable because they allow for international comparisons. Bonoli's classification differentiates between upskilling (e.g. job-related vocational training), employment assistance (e.g. job subsidies), occupation (e.g. public-sector work opportunities) and incentive reinforcement (e.g. sanctions). These measures' objectives differ according to two dimensions: how intensely they focus on human capital development and how much they focus on primary labour market integration.

Programmes are targeted at specific groups. Germany's Hartz IV reforms established measures' cost-effectiveness as a priority: the goal is for welfare recipients' ALMP participation to be successful in improving their employment opportunities (Jacobi \& Kluve, 2007). Welfare recipients with the most beneficial labour market characteristics should not participate in measures. Their participation could inhibit them from taking up employment during participation, referred to as 'lock-in' effects. Their participation could also lead to 'deadweight loss', which means they would have found a job regardless of whether they had participated in a measure. In addition, people furthest from the labour market should take part in measures designed for those with too many obstacles to find a job; namely measures situated in the secondary labour market. Upskilling measures and those supporting primary labour market integration are intended for benefit recipients whose labour market characteristics lie somewhere between these two extremes. However, an exception applies for young adults, as they are at a critical stage in their lifecourse: they should primarily be considered for measures with a human capital focus and primary labour market orientation. In addition, job centres offer specific measures to young adults. Ultimately, the allocation to any programme is dependent on a standardised profiling process that evaluates the client's capabilities and limitations, which nonetheless is highly dependent on caseworkers' discretion.

The objectives of activation measures can be quite different. One the one hand, ALMP programmes that ease school-to-work transitions of young adults during periods of unemployment - mainly by supporting educational attainment and primary labour market work experience - constitute an important part of social investment strategies in European countries (cf. Hemerijck, 2017). These ALMP programmes possess the potential to alleviate social disadvantages. Measures that focus on human capital development and work 
experience in the primary labour market have beneficial effects on labour market integration and thus help overcome welfare reliance.

On the other hand, the Hartz IV reforms have increased benefit conditionality and incentive reinforcement. Germany's reformed Unemployment Benefit II (UBII) established welfare recipients' proactive behaviour 'to improve their situation in a self-responsible way' (Jacobi \& Kluve, 2007 p. $5^{2}$ ) as a condition to avoid benefit sanctions. In fact, UBII stipulates that young welfare recipients in particular must proactively strive to leave the welfare system. The intention is to impede their becoming accustomed to welfare (Bonin et al., 2010). Therefore, sanctions are used to ensure compliance with UBII's conditions, including participation in certain programmes, even when welfare recipients are opposed to participating. Workfare programmes - public-sector work opportunities - have the goal of enabling those furthest from the labour market to gain employability by becoming accustomed to regular work while contributing to society via public unpaid or precariously paid employment. In addition, to monitor proactivity, caseworkers use certain short-term measures as 'work tests'.

This involuntary participation has caught the attention of various scholars, who argue that the state might push some young adults even further away from the labour market by demanding participation in measures (Solga, 2004; Walther \& Plug, 2006). Thus, certain measures can demotivate young adults, particularly when they have a low educational profile and feel as if they are 'being passed over by social policies' (E GRIS 2001, p. 109).

\section{Previous Research on ALMP Programmes Effects}

Cross-national studies comparing different programmes (Caliendo et al., 2011, Card et al., 2018, Heyer et al., 2012) demonstrated public sector employment measures are not as fruitful in (re)integrating people to the labour market as employment assistance in the primary labour market and upskilling measures are. In fact, evaluation results in Germany indicate no or only minimal positive impacts of One-Euro-Jobs (OEJ s), a frequent type of public sector employment measure, on employment and no positive effects on self-efficacy. Instead, they tend to have rather detrimental employment effects on young adults (Harrer \& Stockinger, 2019; Tisch \& Wolff, 2015; Hohmeyer \& Wolff, 2012). Results by Hohmeyer and Wolff (2012) showed that the strongest negative effects of $\mathrm{OEJ} s$ are found for welfare recipients with recent employment experience. Researchers found OEJ $s$ to have positive impacts on alternative outcomes such 
as participants' sense of social integration, given specific conditions, such as their participation being voluntary (Gundert \& Hohendanner, 2015).

In contrast, German classroom training measures are quite ambiguous: while some of them somewhat increase participants' employment perspectives, sub-programmes such as application training show no beneficial effects and are often used as work tests by caseworkers; notably so when such measures were purchased and someone must 'fill the slot'. Likewise, work-placement private services have shown ambiguous effects: a lack of beneficial impacts on young adults in West Germany, but relatively valuable effects in East Germany. The strongest positive employment effects have been found for firm-based upskilling measures: in-firm training and wage subsidy programmes (Heyer et al., 2012; Bernhard et al., 2008; Bernhard \& Wolff, 2008; Harrer et al., 2020; Kopf, 2013). However, researchers have stressed that positive findings of firmbased programmes may conceal substitution effects, deadweight loss or selection bias (e.g. Kopf 2013).

Experimental studies, studies exploiting regional variation and those using a regression discontinuity design have provided mixed findings for the effectiveness of wage subsidies on increasing employment (Liechti et al., 2017 for Switzerland; Wapler et al., 2018 and Schünemann et al., 2013 for Germany). However, positive effects of in-firm training hold steadfast in a study exploiting regional variation (Wapler et al., 2018). Furthermore, although in-firm training is often targeted at welfare recipients who are closer to the labour market, Harrer et al. (2020) indicated effects were similar and even more stable for participants with lower human capital.

\section{Previous Research on ALMP Programmes Selectivity}

While quite a few researchers have analysed Matthew effects among different policies (e.g. Cantillon, 2011; Van Lancker \& Ghysels, 2012), only a few of them have specifically dealt with ALMP. Pisoni (2018) found that programme allocation in Switzerland is based on caseworker's expectations of the success a welfare recipient can achieve during and after participation. She argued this is affected by performance quotas for caseworkers, which provide an incentive to select participants with higher success probabilities. Bonoli and Liechti's (2018) meta-study of ALMP evaluations investigated access biases for lowskilled people and migrants to measures. Regarding training measures, the studies reviewed by the authors found both positive and negative access bias for disadvantaged groups. In contrast, they found a strongly positive access 
bias to public sector job creation measures and a strongly negative access bias to private sector job creation measures, which they understood as a Matthew effect. In Switzerland, Auer and Fossati (2020) showed that the higher the social (geographical, cultural and educational) distance of immigrants, the higher the probability of participating in less beneficial measures. They interpreted this as a 'systematic access bias' for immigrants, who are 'more likely to be parked in ALMP measures with little efficacy' (Auer \& Fossati, 2020 p. 401). Other studies for Germany have found that, for example, the schooling degree positively affects participation in training measures (Osiander and Fertig 2015, Kruppe 2009).

\section{The Matthew Effects Framework in ALMP Evaluation}

'Matthew effects', coined by Merton (1968), constitute an inequality mechanism by which initial advantage generates further advantage. As DiPrete and Eirich (2006) contended, cumulative advantage strictly in Merton's sense implies exponential growth of returns. Others have also applied the concept and that of cumulative (dis)advantage to analyse inequalities in returns between groups. This use corresponds to that of social investment research, where 'Matthew effects' refer to an unintended phenomenon by which those who are better-off benefit more from policies at the expense of the most disadvantaged (Bonoli et al., 2017).

Bonoli et al. (2017) and Bonoli and Liechti (2018) have discussed that while social investment measures should particularly support the most disadvantaged, they may be 'plagued' by Matthew effects. As for ALMP programmes, those that specifically target a determined disadvantaged group should not be affected by Matthew effects. However, 'it may also be the case that, within the overall disadvantaged target population, it will be the least disadvantaged who will be most likely to benefit from these policies' (Bonoli et al., $2017 \mathrm{p}$. 73). That is, the least disadvantaged might have facilitated access to social investment measures; i.e., those that focus on increasing human capital and have a strong primary labour market attachment. We add that if those most disadvantaged were systematically allocated to less beneficial measures, this would also imply a Matthew effect.

In the following, we discuss several mechanisms underlying possible Matthew effects. These mechanisms have already been partially discussed by Bonoli et al. (2017) but we consider additional factors that we deem important.

First, access to certain ALMP programmes, in particular those that involve direct contact with employers, requires capabilities such as cognitive, 
non-cognitive and language skills (Bonoli et al., 2017). One critical aspect signalling a person's productivity is human capital (Becker, 1975), which we measure using work experience and educational level. Educational level can also act as an indicator for cultural capital in the sense of Bourdieu (1996). Education constitutes a fundamental element of cultural capital that is intertwined with other taste-related characteristics classified in the social world such as customs, ambitions and (body) language. As Ludwig-Mayerhofer and colleagues (2009) pointed out, because having little cultural capital shapes a habitus quite different from what an average caseworker - who usually possesses tertiary education - may have, clients and caseworkers might experience 'habitual distance'. Habitual distance might impair cooperation between caseworker and 'client' by thwarting their ability to understand each other. Furthermore, the less educated are likely to have little 'administrative cultural capital'; that is, to lack institutional knowledge key to understanding welfare regulations (Ludwig-Mayerhofer \& Sondermann, 2012). Therefore, human capital, in particular educational level, acts as a marker of one's ability and prestige, both of which make a person more or less suitable for participation in measures.

Second, caseworkers can induce selectivity in participation, referred to as creaming. They may 'anticipate labour-market selectivity and allow participation in ALMP s only to jobless people who can be seen as promising in terms of labour market re-entry' (Bonoli et al., 2017 p. 73). We consider that performance quotas could enhance creaming - caseworkers might prefer investing time and resources in those with fewer barriers to the labour market. By 'picking the winners' they would secure for themselves higher odds of scoring in performance quotas (cf. Brodkin, 2013).

Creaming is however anchored in policy design for some measures. As previously described, firm-based measures were designed for those welfare recipients who need upskilling but are not very distant to the labour market. Workfare measures are destined to those furthest from the labour market; the exception being that young adults should also be considered for upskilling measures. While creaming may be intended to guarantee addressing programme participants' specific needs, it can nonetheless contribute to reproducing social inequalities.

Third, employers enjoy a gatekeeper position for access to in-firm training and wage-subsidy programmes. They may not only influence the overall provision of such programmes on the macro-level (Cronert, 2018) but are also able to impact their street-level application through their hiring practices. To participate in these measures, applicants undergo a screening process with the employer (Brussig et al., 2011, BA 2020b, BA 2019). During this process, it 
is likely that employers take certain signals into account (Weiss, 1995): higher education may be a positive signal for productivity (Di Stasio, 2014), while previous unemployment could send a negative one (Eriksson \& Rooth, 2014).

Fourth, stigmatisation processes might affect measure assignment as well. Reciprocity is a norm in UBII: people receiving help from the state are expected to show work motivation as well as to make efforts to move out of welfare (Lessenich \& Mau, 2005). Caseworkers may then consider people with a low qualification profile to be more 'in debt' to society due to their greater job-finding difficulties (Zahradnik et al., 2016). In this context, Walther (2006 p. 128) stated: 'youth unemployment is interpreted as young people not being ready for this socialization and allocation process, owing to learning or social deficits (in Germany those failing to enter regular apprenticeship training are referred to as 'untrainable')'. Low education might then be a symbol (or stigma) of personal deficit. To oversee these 'lost kids', caseworkers might more likely assign the less educated to workfare or monitoring measures.

In sum, young welfare recipients with lower human capital might face multiple individual, institutional and social barriers to accessing measures that focus on human capital development and/or are located in the primary labour market. Although we cannot directly test each argument previously outlined, we can analyse their overall effect as the theoretical predictions following from them point in the same direction. We thus state:

Hia:Young adults with lower human capital have a lower participation probability in firm-based upskilling and employment assistance measures.

Conversely, short-term classroom measures and measures located in the secondary labour market have low requirements. Although the former can be partially effective in increasing human capital, they might also be used as work tests. Therefore, we expect:

Hib: Young adults with lower human capital have a higher probability of undergoing short-term classroom training and workfare measures.

\section{Further Disadvantage: Intergenerational Transmission of SES}

For young adults whose families were part of the welfare system, there are reasons to believe that difficulties in gaining access to social investment programmes are further amplified.

Parents requiring welfare can bring about detrimental consequences for children through simultaneous context-dependent processes of impoverishment 
affecting their families. In Germany, because long-term benefit collection is a marker for deprivation (Bäcker \& Neubauer, 2018) and families with dependent children rarely exit welfare reliance (Tophoven et al., 2017), children and adolescents on welfare have little access to resources over extended periods of time. This not only refers to nutrition, housing or clothing, but also to sociocultural activities (Christoph et al., 2016; Krug \& Popp, 2008).

For (young) adults, having a family of origin with low SEs (measured e.g. as parental welfare collection) is related to a higher probability of being unemployed and receiving benefits for a long time (e.g. for North America, Hartley et al., 2017; for Scandinavia,; Kauppinen et al., 2014; Wiborg \& Møberg, 2010; for Germany, Siedler, 2004; Schels, 2018). Authors have argued cumulative disadvantages continuously mark the working trajectories of people whose parents are of lower SES. Thus, credentials do not trump the effect of social origin, as meritocratic principles suppose (Kauppinen et al., 2014; Schels, 2018; Wiborg \& Møberg, 2010).

Certain cultural capital aspects may be transmitted over generations above and beyond educational attainment and work experience. This can imply habitual distance to caseworkers and employers, which could lead to creaming and stigmatisation. Such cultural aspects could partially be captured by our measure of welfare experience in the parental household. Therefore, we investigate whether young adults with prior welfare experience confront an additional barrier to having access to measures that cannot be explained by human capital. We state:

H2a: Young adults with prior welfare experience have a lower probability to participate in firm-based measures after controlling for human capital.

$\mathrm{H}_{2}$ b: Young adults with prior welfare experience have a higher probability to undergo short-term classroom training and workfare measures after controlling for human capital.

\section{Data, Method and Programmes}

\section{Data}

We use administrative data from the Statistics Department of the вA in Germany. The population of interest are young adults who receive welfare (UBII) and are capable of working, which is a pre-requisite for programme participation. We draw a stock sample of young adults aged 20 to 22 on July 31, 2014 from this population. We chose this age group because it allows us to have enough information on previous welfare experience during adolescence. (For 
older age groups, we would not have been able to observe welfare receipt during adolescence, as 2005 is the earliest year for which we can observe welfare collection.) We exclude welfare recipients who were in contributory or minor employment or ALMP programmes on July 31, 2014, which would have prevented them from participating in other ALMP programmes. In addition, we excluded those welfare recipients who were not registered as job-seekers on the sample date. Thereby, we ensure that our sample only consists of welfare recipients that can (re)integrate into the labour market. Finally, we excluded those welfare recipients with inconsistent or insufficient information, which only concerned a minor share of the sample (less than 0.5 per cent of the original number of job seekers). Table 1 summarizes selected covariates of the sample. In sum, the sample contains 67,410 individuals.

A central independent variable is welfare collection during adolescence (see Table 1). We were able to observe individuals' welfare histories back to 2005 (before 2005, no data on household members was collected for benefit recipients in the former welfare system). On July 31,2005 , the sample members were aged 11 to 14 . Hence, the maximum period they could have received welfare differs for the sample members depending on their age at the sampling date. To deal with this problem, we analyse sample members' welfare receipt as members of their parents' households over the age span of 14 to 17 , which

TABLE 1 Descriptive statistics of selected covariates

\begin{tabular}{|c|c|c|c|}
\hline & $N$ & Mean & S.D. \\
\hline Female & 31,683 & 0.47 & $0.5^{\circ}$ \\
\hline East: East (incl. Berlin) & 19,387 & 0.29 & 0.45 \\
\hline Education: No schooling and no vocational degree & 7,485 & 0.11 & 0.31 \\
\hline $\begin{array}{l}\text { Education: Lower secondary without vocational } \\
\text { degree }\end{array}$ & 40,338 & o.6o & 0.49 \\
\hline $\begin{array}{l}\text { Education: Upper secondary, vocational degree } \\
\text { or higher }\end{array}$ & 15,964 & 0.24 & 0.43 \\
\hline Education: Missing & 3,623 & 0.05 & 0.23 \\
\hline Welfare receipt in years (age 14-18) & & 1.92 & 1.74 \\
\hline Employment duration in years & & 0.23 & 0.48 \\
\hline Total number of observations ${ }^{\text {a }}$ & 67,410 & & \\
\hline
\end{tabular}

a Total number of observations after the data preparation described in the data section. For the analysis, observations are excluded based on a random programme start procedure as described in the method section. See appendix table B.2 for the number of observations by programme and treatment status. 
is available for all sample members. Prior welfare collection is specified as the number of days in the welfare system during this period rescaled to years.

Further central independent variables refer to human capital operationalised by employment experience in contributory employment (in days, rescaled to years) and education (see Table 1). To improve international comparability, we built a three-level education variable using the International Standard Classification of Education 2011. Level 1 refers to people with neither secondary school completion nor any kind of further training. Level 2 encompasses people whose highest educational attainment is low secondary education ('Hauptschule' and 'Realschule'). Lastly, level 3 includes all those who attained upper secondary education ('Abitur') and/or vocational training. Because not many have attained a higher degree, those better educated are also grouped in level 3 .

In addition, we include a wide range of control variables. The full overview of covariates included in the model estimation and descriptive statistics can be found in appendix table B.3. Control variables include socio-demographics (e.g. gender and age group), household characteristics (e.g. household type, partner's information), previous employment history (e.g. duration in employment) and regional characteristics (e.g. district unemployment rate). As parents caring for young children under the age of three are seldom required to participate in ALMP programmes (Zabel, 2012), we control for age of the youngest child in our analyses.

Our dependent variable is an indicator for ALMP programme participation in the six months following our sampling date: that is, in the time window from August 1, 2014 to January 31, 2015. We chose a comparatively long time window of six months to observe a sufficient number of ALMP programme entries for our narrowly defined age group of 20-22 year old welfare recipients.

\section{Method}

We run separate logit models for participation in each of the different ALMP programmes delineated below. For each type of programme, we are interested in the first ALMP programme entry during our observation window.

In logistic regression models, the coefficient size is difficult to interpret. We therefore calculate the average marginal effect (AME); i.e. the sample average of individual marginal effects (Cameron \& Trivedi, 2005 p. 467; Mood, 2010 p. 75). Furthermore, we calculate semi-elasticities that can be interpreted as the relative change in the dependent variable with a one-unit change in the independent variable. The technical details of this approach are described in Appendix A. 
A methodological problem comes about wherein sample members with specific characteristics that are favourable for employment opportunities may leave welfare receipt or unemployment very quickly. These sample members are unlikely to be assigned to ALMP programmes simply because they are not available as welfare benefit recipients long enough to be assigned to ALMP programmes. Thus, following a procedure similar to that used by Hohmeyer and Wolff (2012) or Harrer et al. (2O20), we excluded non-participants from the sample if they left welfare receipt or unemployment before the time of a randomly assigned date based on the distribution of actual programme start dates for the ALMP programme of interest in the sample. As the distribution of ALMP programme start dates is different for each programme we analyse, a different number of non-participants is excluded each time, and the sample size thusly varies across the models we estimate for participation in each type of programme. In the end, people included in or excluded from one model can appear in another one, whether they had been treated or not.

\section{Programmes}

To test our hypotheses, we compare participation probabilities in a range of ALMP programmes. First, for firm-based upskilling measures, we analyse shortterm in-firm training measures. In in-firm training measures, participants undertake an unpaid internship with a firm for up to four weeks. The purpose is to help the participant gain some work experience and become familiar with the employer and work schedule (Harrer et al., 2020). In 2014, around 170,000 participations took place for UBII recipients.

Another set of short-term measures are outsourced measures, in which a private establishment provides various types of classroom training and, less often, supports participants in finding a job. Mainly, these measures aim to improve skills and ameliorate skill 'deficit'. Job centres, however, also use these measures to monitor client's availability and effort to find a job. Outsourced programmes constitute the largest ALMP measure: nearly 670,000 outsourced training and placing participations took place in 2014 (Heyer et al., 2012; Harrer et al., 202O; Statistics Department of the FLA, 2017).

For employment assistance, we analyse wage subsidies. Such subsidies can either be directed to the employer ('Eingliederungszuschüsse', EGz) or to the employee ('Einstiegsgeld', ESG) and, hence, support employment integration in the primary labour market. The maximum entitlement duration of EGZ is twelve months and the maximum amount of entitlement is $50 \%$ of the wage received (Bernhard et al., 2008; BA, 2020a). ESG's entitlement duration is 24 months at maximum and the support is either provided as an individual benefit, depending on multiple factors such as household needs or previous unemployment 
experience, or as a flat-rate benefit (BA, 2020b). In 2014, about 110,000 wage-subsidy measures took place (Statistics Department of the FLA, 2020).

For public sector employment, we analyse OEJ $\mathrm{s}$, which is considered a workfare programme (Hohmeyer \& Wolff, 2012; Zabel, 2013). OEJ s are work opportunities that mainly take place in the public and non-profit sector and for which participants receive a compensation of about one to two Euros per hour, in addition to their regular benefit. They are said to be a 'last resort' of ALMP targeted at those furthest from the labour market. Since the reform in 2012, young welfare recipients below the age of 25 are no longer a target group of OEJ s (Harrer \& Stockinger, 2019). In 2014, however, about $9 \%$ of the 260,000 people who started participation in an OEJ were under 25 years of age (Statistics Department of the FLA, 2015, 2020).

\section{Results}

Table 2 reports the results from the logit estimations separately by the type of programme. Because of space limitation, we only report the average marginal effects and semi-elasticities of our central independent variables, including previous welfare experience, educational degrees and previous employment experience. (The reader can find the full coefficient estimates of the main models including all control variables in appendix C.)

\section{ALMP Measures and Those with Lower Human Capital}

Our first expectation (Hia) was that young adults with lower human capital would have a lower participation probability in upskilling and employment assistance measures with direct contact to employers.

For in-firm training measures, education plays a relevant role for the participation probability. As the baseline probabilities of programme participation are quite low, we report effects in absolute as well as in relative terms. In absolute terms, a lower secondary certificate on average increases the probability of participating by 0.7 percentage points (pp) (significant at the $1 \%$ level). In relative terms, this translates into a $33 \%$ higher probability of taking part in in-firm training for those with this educational certificate than for those lacking any certification. In comparison, a higher educational degree raises the participation probability by roughly $2 \mathrm{pp}$, or, in relative terms, almost twice the probability to participate in in-firm measures compared to those with the lowest educational level. Concerning work experience, one additional year increases the participation probability by $0.7 \mathrm{pp}$ (or $26 \%$ in relative terms). The last two effects are highly significant. 


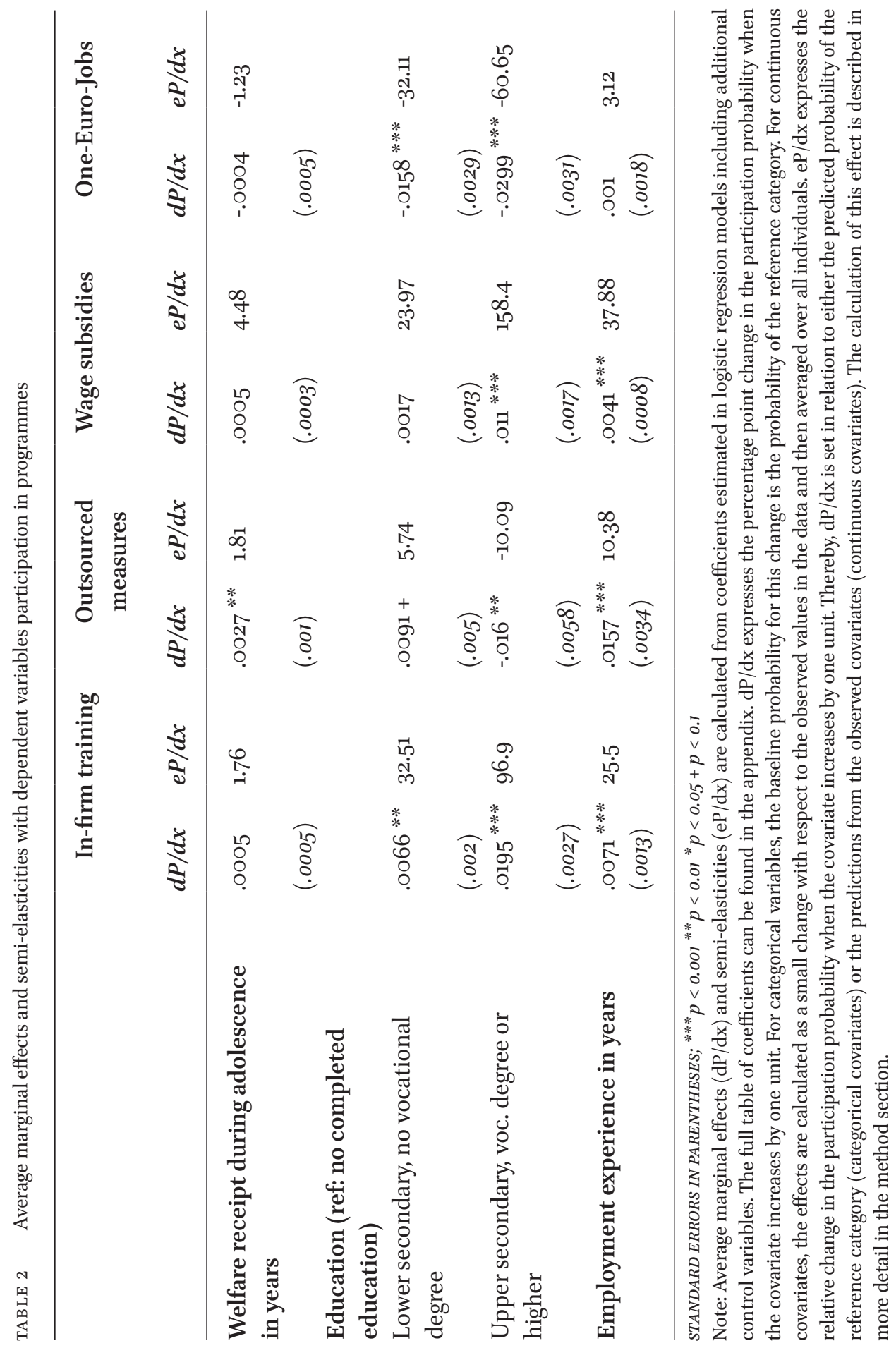


As for wage subsidies, a lower secondary certificate has no significant effect compared to having no educational degree. Conversely, a higher educational level displays a strong effect. Although the increase in participation probability of $1.1 \mathrm{pp}$ seems moderate, in relative terms, young adults with higher levels of education have a $158 \%$ higher probability of participation than those with the lowest educational level. (This immense difference relates to the low base probability of participation for individuals without an educational degree of less than $0.7 \%$ ). Moreover, one additional year of work experience increases the participation probability by 0.4 pp or $38 \%$.

These results are in line with Hia. While we find a noteworthy positive impact of education on participating in in-firm training, effects of education on receiving a wage subsidy demonstrate it is a much more selective measure; targeted mainly at better-educated young adults.

We also anticipated that young adults with lower human capital would have a higher probability to undergo classroom training measures and an even higher probability to undergo public-sector employment measures (Hib).

Table 2 shows that having a lower-secondary school degree raises the probability of participating in an outsourced measure (including short-term in-class training and placement services) by approx. $0.9 \mathrm{pp}$ or, in relative terms, young adults with this degree possess a $6 \%$ higher probability than those lacking in education. (This effect is only significant at the $10 \%$ level, however.) Young adults who attained an upper secondary or vocational training degree (or higher) are less likely by $1.6 \mathrm{pp}$ to participate in outsourced measures at the $1 \%$ significance level. In terms of semi-elasticities, they have a $10 \%$ lower probability of participation than young adults without a schooling degree. While this confirms our expectation Hib, employment experience shows a positive and highly significant effect. One additional year of work experience increases the participation probability by $1.6 \mathrm{pp}$ (or 10\% in terms of semi-elasticities).

Results for participation in OEJ $\mathrm{s}$ are remarkable. The participation probability in OEJ $\mathrm{s}$ is particularly high for lower qualified individuals: having a low secondary degree decreases the participation probability by $1.6 \mathrm{pp}$ compared to those without a degree. In relative terms, their participation probability is $3^{2} \%$ lower. Likewise, the effect of an upper secondary or higher degree is minus $3 \mathrm{pp}$. In relative terms, those with a higher degree possess a $61 \%$ lower probability to be assigned to an OEJ than those with no school completion. In contrast to the previously described findings on other measures, employment experience has no significant effect on participation in OEJ $\mathrm{S}$.

These two results support our Hib, albeit with certain restrictions. Effects are more ambiguous for outsourced measures than for oEJ s. The probability of participating in outsourced measures is higher for the lower-educated, 
altogether. Employment experience, in contrast, possesses a positive effect on participation. These contradictory effects of human capital may reflect the ambiguity of this kind of measures: on the one hand, they include an upskilling component, on the other hand, they are used to monitor job-search efforts of clients.

\section{ALMP s and Those with Low SES of Origin}

Due to the crucial importance of social origin, we proposed that being in the welfare system between the ages of 14 and 17 would have an impact on participation in ALMP measures even after controlling for human capital. We stated that young adults with such experience would have a lower participation probability in firm-based measures (H2a) and a higher probability to undergo classroom training and workfare measures $\left(\mathrm{H}_{2} b\right)$. We, fortunately, find no consistent support for any of these expectations.

Only in the case of outsourced schemes does prior welfare experience have a significant effect on the probability of participation. Results in Table 2 reveal that one additional year of prior welfare experience between ages 14 and 17 increases the probability of taking part in outsourced measures by $0.3 \mathrm{pp}$. In relative terms, the participation probability of those with one additional year of prior experience increases by roughly $2 \%$.

To examine effect heterogeneity concerning prior welfare experience, we performed additional analyses differentiating between East and West Germany and between men and women, but found most estimates to be neither significantly different from zero nor significantly different from each other across all programmes evaluated, with few exceptions (find Figure 1 in appendix D; complete results available on request).

Hence, prior welfare experience from age 14 to 17 plays only a minor role for the assignment to ALMP programmes exclusively for specific subgroups and programmes. We performed further sensitivity checks on the main models, also available to the reader upon request. To test whether education mediates the overall effect of previous welfare experience, we estimated logistic regressions without the variable education and found no essential changes in the results. In addition, we controlled for nonlinearity including a categorical version of the welfare experience variable. This test showed that possible nonlinearities alter results only minimally. Finally, we estimated the regression models with district-clustered standard errors (see appendix table F.1) and as multi-level models with district as the cluster level (available upon request). The coefficient estimates do not change strongly. However, the positive effect of welfare receipt on participation in wage subsidy measures becomes significant. This runs even contrary to our expectations. Therefore, we reject both $\mathrm{H} 2 \mathrm{a}$ and $\mathrm{H} 2 \mathrm{~b}$. 


\section{Conclusion}

In recent years, the importance of social investment for overcoming young people's educational disadvantages and barriers to employment has been emphasised by EU policy initiatives. In Germany, educational credentials are particularly important for successful labour market entry (Shavit \& Müller, 1998; Walther, 2006). At the same time, low intergenerational mobility still marks Germany (Minello \& Blossfeld, 2017). Against this backdrop, this article has examined whether participation in measures by adults aged $20-22$ receiving UBII is biased.

Our findings indicate that young welfare recipients with lower human capital have lower probabilities of participating in firm-based measures. Welfare recipients with little employment experience or education are not the primary target groups of in-firm training or wage subsidies in part due to the assumption that they would not benefit from these measures. Nevertheless, previous research has shown that these measures are most beneficial for enhancing employment opportunities, especially in the case of benefit recipients with low prior resources. Furthermore, limited access for the most disadvantaged can also arise from employer's preferences, who then act as gatekeepers to in-firm training and subsidised jobs.

The participation probability in outsourced measures is higher for those with lower education but, contrary to what we expected, employment experience increases the participation probability. This ambiguous effect might be due to the ambiguity of these measures themselves - we considered them monitoring measures because they are often used as such, though they also contain an upskilling element.

Lower-educated young adults have a higher probability of participation in workfare programmes. As far as this measure targets low-qualified welfare recipients in general, OEJs reach their target group. However, young welfare recipients are no longer a target group of OEJs. Given the evidence on negative effects of OEJs on later labour market outcomes for young adults, this selectivity may contribute to increasing differences between groups with differing human capital.

We further expected that prior welfare experience in their parents' household could decrease young adults' access to measures with a stronger focus on social investment and increase their referral to workfare and monitoring measures. We expected such a continued effect of prior welfare experience, regardless of individual human capital. We find no evidence supporting this hypothesis.

However, a limitation of our study is that welfare experience during adolescence is an imperfect measure of SES of the family of origin. This measure is available for all sample members though. It would have been worthwhile to 
study the effect of parental characteristics more directly. Our data does not allow us to do this. Another limitation of our study is that we cannot disentangle the effects of each mechanism causing inequality in measure access. Future research could investigate such mechanisms as well as other intergenerational mechanisms in more depth, possibly using qualitative methods.

It is reassuring to know that young welfare recipients with a longer history of welfare benefits in their parents' household hardly seem to face additional disadvantages concerning access to measures with a stronger focus on social investment. Nevertheless, that most young adults on welfare have already been welfare recipients as adolescents indicates substantial persistence of socio-economic disadvantages across generations.

Concerning the influence of education and employment experience, in contrast, we would argue that our findings indicate the presence of Matthew effects, as the most disadvantaged have the least access to social investment measures. Instead, they are often assigned to measures that do not increase their employment perspectives. Recalling Solga's (2004) and Walther and Plug's (2006) argument that repeated participation in such programmes could demotivate less-educated young adults, such participation might discourage them from reintegrating into the educational system or labour market. Furthermore, since disadvantages in access to work and educational opportunities cumulate and intensify across the lifecourse (Solga, 2002), young people who are worse-off urgently need opportunities to gain skills and enter the first labour market. We recognise there is a need to widen the scope of ALMP measures that focus on social investment. Those investigated in this paper that have been proven beneficial for participants mainly take place in the primary labour market, where young adults already have failed to find an opportunity. As institutional creaming is prevalent and employers are the gatekeepers of the main social investment measures, more effective strategies may be needed to give young adults who are more disadvantaged a chance to gain employment experience via these measures. As has recently been implemented in the German initiative 'Sozialer Arbeitsmarkt' for long-term, often older, welfare recipients, coaching during firm-based measure participation could be an option to support young adults in stabilising their employment as well.

\section{Acknowledgements}

We are very grateful to Brigitte Schels, Joachim Wolff and two anonymous reviewers for very helpful comments and advice. We thank Brittany Dennee for her support as well as Leon Löppert, Aylin Steyer and Laurenz Dischinger for excellent research assistance. 


\section{References}

Allmendinger, J. (1989). Educational Systems and Labor Market Outcomes. European Sociological Review 5 (3), pp. 231-50.

Auer, D. and Fossati, F. (2020). Compensation or Competition: Bias in Immigrants' Access to Active Labour Market Measures. Social Policy \& Administration 54 (3), pp. 390-409.

BA (Bundesagentur für Arbeit/Federal Employment Agency). (2019). Maßnahmen bei einem Arbeitgeber (MAG) nach § 45 SGB III im Rahmen der Maßnahmen zur Aktivierung und beruflichen Eingliederung. Fachliche Weisung zur Durchführung des $\S 45$ SGB III. Link: https://www.arbeitsagentur.de/datei/ba146324.pdf [last accessed: o6.07.2021].

BA (Bundesagentur für Arbeit/Federal Employment Agency). (2020a). Fachliche Weisungen zum Eingliederungszuschuss $§ \S 88$ - 92 SGB III. Link: https://www. arbeitsagentur.de/datei/dok_bao14612.pdf [last accessed: 06.07.2021].

BA (Bundesagentur für Arbeit/Federal Employment Agency). (2020b). Fachliche Weisungen Zweites Buch Sozialgesetzbuch - SGB II. § 16b SGB II Einstiegsgeld. Link: https://www.arbeitsagentur.de/datei/fw-sgb-ii-16b_bao15829.pdf [last accessed: o6.07.2021].

Bäcker, G. and Neubauer, J. (2018). Arbeitsförderung und Grundsicherung: Ansätze, Ergebnisse und Risiken. In: E.-U. Huster , J. Boeckh and H. Mogge-Grotjahn ed., Handbuch Armut und soziale Ausgrenzung. Wiesbaden: Springer vs, pp. 395-414.

Becker, G.S. (1975). Human Capital: A Theoretical and Empirical Analysis, with Specific Reference to Education. 2 ed. New York: National Bureau of Economic Research.

Bernhard, S., Brussig, M., Gartner, H. and Stephan, G. (2008). Eingliederungszuschüsse für ALG-II-Empfänger: Geförderte haben die besseren Arbeitsmarktchancen. IAB-Kurzbericht 12/2008.

Bernhard, S. and Wolff, J. (2008). Contracting Out Placement Services in Germany: Is Assignment to Private Providers Effective for Needy Job-Seekers? IAB-Discussion Paper $5 / 2008$.

Best, H. and Wolf, C. (2012). Modellvergleich und Ergebnisinterpretation in Logit-und Probit-Regressionen. KZfSS Kölner Zeitschrift für Soziologie und Sozialpsychologie, 64 (2), pp. 377-395.

BMFSJ (Bundesministerium für Familie, Senioren, Frauen und Jugend/ Federal Ministry for Family Affairs, Senior Citizens, Women and Youths), (2019). In gemeinsamer Verantwortung: Politik für, mit und von Jugend. Die Jugendstrategie der Bundesregierung. Link: https://www.bmfsfj.de/blob/14194o/ a9789d196ec8313bob6bda4d5fd18eae/in-gemeinsamer-verantwortung-politik-fuermit-und-von-jugend-data.pdf [last accessed: 07.07.2021].

Bonin, H., Fries, J., Maier, M., Walter, T., Schröder, H., Niedlich, S., Oschmiansky, F. and Stegner, K. (2010). Vorstudie zur Evaluation von Förderungsmaßnahmen für Jugendliche 
im SGB II und SGB III. Endbericht. Mannheim: Bundesministerium für Arbeit und Soziales; Zentrum für Europäische Wirtschaftsforschung (ZEW) GmbH; infas - Institut für Angewandte Sozialwissenschaft $\mathrm{GmbH}$; Ramboll Management $\mathrm{GmbH}$.

Bonoli, G. (2010). The Political Economy of Active Labor-Market Policy. Politics and Society 38 (4), pp. 435-57.

Bonoli, G., Cantillon, B. and Van Lancker, W. (2017). Social Investment and the Matthew Effect. In: A. Hemerijck ed., The Uses of Social Investment. New York: Oxford University Press, pp. 66-76.

Bonoli, G. and Liechti, F. (2018). Good Intentions and Matthew Effects: Access Biases in Participation in Active Labour Market Policies. Journal of European Public Policy 25 (6), pp. 894-911.

Bourdieu, P. (1996). Distinction. A Social Critique of the Judgement of Taste. 8 ed. Cambridge/Massachusetts: Harvard University Press.

Brodkin, E.Z. (2013). Street-Level Organizations and the Welfare State. In: E. Z. Brodkin and G. Marston ed., Work and the Welfare State. Street-Level Organizations and Workfare Politics. Washington: Georgetown University Press, pp. 17-34.

Brussig, M., Schwarzkopf, M. and Stephan, G. (2011). Eingliederungszuschüsse: Bewährtes Instrument mit zu vielen Varianten. IAB-Kurzbericht 12/2011.

Caliendo, M., Künn, S. and Schmidl, R. (2011). Fighting Youth Unemployment: The Effects of Active Labor Market Policies. IZA Discussion Paper 6222.

Cameron, A.C. and Trivedi, P.K. (2005). Microeconometrics: Methods and Applications. Cambridge: Cambridge University Press.

Cantillon, B. (2011). The Paradox of the Social Investment State: Growth, Employment and Poverty in the Lisbon Era. Journal of European Social Policy 21 (5), pp. 432-49.

Card, D., Kluve, J. and Weber, A. (2018). What Works? A Meta Analysis of Recent Active Labor Market Program Evaluations. Journal of the European Economic Association 16 (3), pp. 894-931.

Christoph, B., Lietzmann, T., Tophoven, S. and Wenzig, C. (2016). Materielle Lebensbedingungen von SG B-II-Leistungsempfängern. Aktuelle Berichte 21/2016.

Cronert, A. (2018). Accommodation or Extraction? Employers, the State, and the Joint Production of Active Labor Market Policy. Politics \& Society 46 (4), pp. 539-69.

Di Stasio, V. (2014). Education as a Signal of Trainability: Results from a Vignette Study with Italian Employers. European Sociological Review 30 (6), pp. 796-8og.

DiPrete, T.A. and Eirich, G.M. (2006). Cumulative Advantage as a Mechanism for Inequality: A Review of Theoretical and Empirical Developments. Annual Review of Sociology 32, pp. 271-97.

EC (European Commission) (2012). Moving Youth into Employment. Link: http:// ec.europa.eu/social/BlobServlet?docId=9223\&langId=en [last accessed: 29.10.2020].

EC (European Commission) (2013). Towards Social Investment for Growth and Cohesion - Including Implementing the European Social Fund 2014-2020. Link: http://aei.pitt.edu/45911/ [last accessed: o6.07.2021]. 
EC (European Commission) (2018). Situation of Young People in the European Union. Link: https://op.europa.eu/en/publication-detail/-/publication/b6985coc- $743^{\mathrm{f}}$ 11e8-9483-o1aa75ed71a1 [last accessed: 29.10.2020].

Eriksson, S. and Rooth, D.-O. (2014). Do Employers Use Unemployment as a Sorting Criterion When Hiring? Evidence from a Field Experiment. American Economic Review 104 (3), pp. 1014-39.

Eurofound (European Foundation for the Improvement of Living and Working Conditions) (2014). Mapping Youth Transitions in Europe. Luxembourg: Publications Office of the European Union.

Eurofound (European Foundation for the Improvement of Living and Working Conditions) (2017). Long-Term Unemployed Youth: Characteristics and Policy Responses. Luxembourg: Publications Office of the European Union.

European Group for Integrated Social Research (EGRIS). (2001). Misleading Trajectories: Transition Dilemmas of Young Adults in Europe. Journal of Youth Studies 4 (1), pp. 101-18. Groh-Samberg, O. and Voges, W. (2014). Precursors and Consequences of Youth Poverty in Germany. Longitudinal and Life Course Studies 5 (2), pp. 151-72.

Gundert, S. and Hohendanner, C. (2015). Active Labour Market Policies and Social Integration in Germany: Do 'One-Euro-Jobs' Improve Individuals' Sense of Social Integration? European Sociological Review 31 (6), pp. 780-97.

Harrer, T., Moczall, A. and Wolff, J. (2020). Free, Free, Set Them Free? Are Programmes Effective That Allow Job Centres Considerable Freedom to Choose the Exact Design? International Journal of Social Welfare 29 (2), pp. 154-67.

Harrer, T. and Stockinger, B. (2019). Ein-Euro-Jobs nach der Instrumentenreform 2012. Zielgruppe besser erreicht - erste Ergebnisse zur Wirkung. IAB-Kurzbericht 22/2019. Hartley, R., Lamarche, C. and Ziliak,J.P. (2017). Welfare Reform and the Intergenerational Transmission of Dependence. IZA Discussion Paper 10942.

Hemerijck, A. (2017). Social Investment and its Critics. In: A. Hemerijck ed., The Uses of Social Investment. New York: Oxford University Press, pp. 3-39.

Heyer, G., Koch, S., Stephan, G. and Wolff, J. (2012). Evaluation der aktiven Arbeitsmarktpolitik: Ein Sachstandsbericht für die Instrumentenreform 2011. Journal for Labour Market Research 45 (1), pp. 41-62.

Higgins, J. (2018). Labour Market Change: Europe's Long-Term Issue: Youth Unemployment. Link: eurofound.link/efi8o82 [last accessed: 29.10.2020].

Hohmeyer, K. and Wolff, J. (2012). A Fistful of Euros: Is the German One-Euro Job Workfare Scheme Effective for Participants? International Journal of Social Welfare 21 (2), pp. 174-85.

Jacobi, L. and Kluve, J. (2007). Before and After the Hartz Reforms: The Performance of Active Labour Market Policy in Germany. Journal for Labour Market Research (Zeitschrift für ArbeitsmarktForschung) 40 (1), pp. 45-64.

Kauppinen, T.M., Angelin, A., Lorentzen, T., Bäckman, O., Salonen, T., Moisio, P. and Dahl, E. (2014). Social Background and Life-Course Risks as Determinants of Social 
Assistance Receipt Among Young Adults in Sweden, Norway and Finland.Journal of European Social Policy 24 (3), pp. 273-88.

Kopf, E. (2013). Short Training for Welfare Recipients in Germany: Which Types Work? International Journal of Manpower 34 (5), pp. 486-516.

Krug, G. and Popp, S. (2008). Soziale Herkunft und Bildungsziele von Jugendlichen im Armutsbereich. IAB-Discussion Paper 42/2008.

Kruppe, T. (2009). Bildungsgutscheine in der aktiven Arbeitsmarktpolitik. Sozialer Fortschritt $5^{8}$ (1), pp. 9-19.

Lessenich, S. and Mau, S. (2005). Reziprozität und Wohlfahrtsstaat. In: F. Adloff and S. Mau ed., Vom Geben und Nehmen. Frankfurt am Main: Campus, pp. 257-76.

Liechti, F., Fossati, F., Bonoli, G. and Auer, D. (2017). The Signalling Value of Labour Market Programmes. European Sociological Review 33 (2), pp. 257-74.

Ludwig-Mayerhofer, W., Behrend, O. and Sondermann, A. (2009). Auf der Suche nach der verlorenen Arbeit. Konstanz: UVK Verlagsgesellschaft.

Ludwig-Mayerhofer, W. and Sondermann, A. (2012). „Fordern und Fordern... aber wen eigentlich?“. In: M. Bereswill, C. Figlestahler, L. Y. Haller, M. Perels and F. Zahradnik ed., Wechselverhältnisse im Wohlfahrtsstaat. Muenster: Westfälisches Dampfboot, pp. 194-211.

Merton, R.K. (1968). The Matthew Effect in Science. Science 159 (3810), pp. 56-63.

Minello, A. and Blossfeld, H.-P.(2017). From Parents to Children: The Impact of Mothers' and Fathers' Educational Attainments on those of their Sons and Daughters in West Germany. British Journal of Sociology of Education 38 (5), pp. 686-704.

Mood, C. (2010). Logistic Regression: Why We Cannot Do What We Think We Can Do, and What We Can Do About It. European Sociological Review 26 (1), pp. 67-82.

Müller, W. and Gangl, M. (2003). Transitions from Education to Work in Europe: The Integration of Youth Into EU Labour Markets. Oxford: Oxford University Press.

Osiander, C. and Fertig, M. (2015). Selektivität beim Zugang zu Weiterbildungsmaßnahmen. Die Bedeutung individueller und struktureller Determinanten am Beispiel der "Initiative zur Flankierung des Strukturwandels". Journal of Contextual Economics - Schmollers Jahrbuch 135 (3), pp. 279-306.

Pisoni, D. (2018). Between Idealism and Pragmatism: Social Policies and Matthew Effect in Vocational Education and Training for Disadvantaged Youth in Switzerland. Social Inclusion 6 (3), pp. 289-30o.

Schels, B. (2018). Young Adults' Risk of Long-Term Benefit Receipt and Parents' Socioeconomic Background. Acta Sociologica 61 (1), pp. 17-33.

Schoon, I. and Bynner, J. (2019). Young People and the Great Recession: Variations in the School-to-Work Transition in Europe and the United States. Longitudinal and Life Course Studies 10 (2), pp. 153-73.

Schünemann, B., Wunsch, C. and Lechner, M. (2013). Do Long-Term Unemployed Workers Benefit from Targeted Wage Subsidies? German Economic Review 16 (1), pp. $43^{-64}$. 
Shavit, Y. and Müller, W. (1998). From School to Work: A Comparative Study of Educational Qualifications and Occupational Destinations. Oxford: Clarendon Press.

Siedler, T. (2004). Is the Receipt of Social Assistance Transmitted from Parents to Children?: Evidence from German Panel Data.

Solga, H. (2002). 'Stigmatization by Negative Selection': Explaining Less-Educated People's Decreasing Employment Opportunities. European Sociological Review 18 (2), pp. 159-78.

Solga, H. (2004). Increasing Risks of Stigmatization: Changes in School-To-Work Transitions of Less-Educated West Germans. Yale Journal of Sociology 4, pp. 99-129. Stata. Stata Manual. Chapter 13 - Margins.

Statistics Department of the F LA.(2015). Leistungen zur Eingliederung an erwerbsfähige Hilfebedürftige: Einsatz von Arbeitsgelegenheiten 2014. Link: https://statistik. arbeitsagentur.de [last accessed: 29.10.2020].

Statistics Department of the FLA. (2017). Data Ware House.

Statistics Department of the FLA. (2020). Arbeitsmarktpolitische Instrumente. (Zeitreihe Jahreszahlen). Nürnberg, März 2020.

Tisch, A. and Wolff, J. (2015). Active labour market policy and its outcomes. Does workfare programme participation increase self-efficacy in Germany? International Journal of Sociology and Social Policy 35 (1/2,), pp. 18-46.

Tophoven, S., Lietzmann, T., Reiter, S. and Wenzig, C. (2017). Armutsmuster in Kindheit und Jugend: Längsschnittbetrachtungen von Kinderarmut. Link: https://www. bertelsmann-stiftung.de/de/publikationen/publikation/did/armutsmuster-inkindheit-und-jugend/ [last accessed: 29.10.2020].

Van Lancker, W. and Ghysels, J. (2012). Who Benefits? The Social Distribution of Subsidized Childcare in Sweden and Flanders. Acta Sociologica 55 (2), pp. 125-42.

Walther, A. (2006). Regimes of Youth Transitions: Choice, Flexibility and Security in Young People's Experiences Across Differenct European Contexts. Young: Nordic Journal of Youth Research 14, pp. 119-39.

Walther, A. and Plug, W. (2006). Transitions From School to Work in Europe: Destandardization and Policy Trends. New Directions for Child and Adolescent Development 2006 (113), pp. 77-9o.

Wapler, R., Wolf, K. and Wolff, J. (2018). Do active labour market policies for welfare recipients in Germany raise their regional outflow into work? IAB Discussion Paper 2018 (8), pp. 1-41.

Weiss, A. (1995). Human Capital vs. Signalling Explanations of Wages. Journal of Economic Perspectives 9 (4), pp. 133-54.

Wiborg, Ø.N. and Møberg, R.J. (2010). Social Origin and the Risks of Disadvantage in Denmark and Norway: The Early Life Course of Young Adults. Work, Employment and Society 24 (1), pp. 105-25.

Williams, R. (2012). Using the Margins Command to Estimate and Interpret Adjusted Predictions and Marginal Effects. The Stata Journal, 12 (2), pp. 308-331. 
Zabel, Cordula (2012). Adult workers in theory or practice? Lone mothers' participation in active labour market programmes in Germany. Journal of Comparative Social Work, 7 (2), n. pag.

Zabel, Cordula (2013). Does activation increase lone mothers' employment chances? * effects of training and workfare for lone mothers receiving means-tested benefits in Germany. The International Journal of Sociology and Social Policy, 33 (7/8), pp. 453-473.

Zahradnik, F., Schreyer, F., Moczall, A., Gschwind, L. and Trappmann, M. (2016). Wenig gebildet, viel sanktioniert? Zur Selektivität von Sanktionen in der Grundsicherung des SG B II. Zeitschrift für Sozialreform 62 (2), pp. 141-80.

\section{Appendices}

\section{Appendix A Technical Details on the Methodological Approach}

In logistic regression models, the coefficient size is difficult to interpret. To provide a more intuitive understanding, scholars suggest calculating marginal effects (Best \& Wolf 2012; Mood 2010). A problem arises because marginal effects depend on the value at which covariates in the model are fixed. One way to deal with this has been to fix covariate values at their means, reflecting an 'average' person in the data (Williams 2012 p. 323). The downsides of such an approach are evident: first, for binary or categorical variables, the mean may have no substantive interpretation. Second, such a calculation does not take different effect sizes across the distribution of the covariate into account. This might be of particular relevance if the distribution is strongly skewed. Instead, authors have proposed to calculate the average marginal effect (AME), i.e. the sample average of individual marginal effects (Cameron and Trivedi 2005, p. 467; see also Mood 2010 p. 75; Williams 2012 p. 324-326). This approach includes the whole observed distribution of the covariates in the calculation of the marginal effect. We therefore calculate AME and semi-elasticities using the margins command of Stata 16 (see Stata manual chapter 13).

The calculation of AME requires the individual predictions of

$$
P\left(y_{i}=1 \mid x_{i}, w_{i}\right)=P_{i}=\frac{\exp \left(x_{i} \beta_{x}+\boldsymbol{w}_{i}{ }^{\prime} \boldsymbol{\beta}_{w}\right)}{1+\exp \left(x_{i} \beta_{x}+\boldsymbol{w}_{i}^{\prime} \boldsymbol{\beta}_{w}\right)}
$$

calculated with the vector of individual covariates $\boldsymbol{x}_{i}=\left(x_{i}, \boldsymbol{w}_{i}\right)$ and the estimate of their parameter vector $\boldsymbol{\beta}=\left(\boldsymbol{\beta}_{\boldsymbol{x}}, \boldsymbol{\beta}_{\boldsymbol{w}}\right)$ estimated in the logistic regression model. For the binary covariate $x_{i}$, AME can be expressed as a change from o to 1 :

$$
d P(y=1 \mid x, \boldsymbol{w}) / d x=E\left(d P_{i} / d x_{i}\right)=E\left(P\left(1 \beta_{x}+w_{i}^{\prime} \beta_{w}\right)-P\left(0 \beta_{x}+w_{i}^{\prime} \beta_{w}\right)\right)
$$


whereby $\boldsymbol{\omega}_{i}{ }^{\prime}$ includes the constant and the other covariates included in the model held fixed at their observed values. Hence, for categorical covariates AME is calculated as the difference in average predictions for the category of interest with respect to the reference category.

For continuous variables, AME is calculated as the derivative of $P=P(y=1 \mid x, \boldsymbol{w})$ with respect to $x$. Formally, this can be expressed as follows:

$d P(y=1 \mid x, \boldsymbol{w}) / d x=E\left(d P_{i} / d x_{i}\right)=E\left(\frac{P\left(\left(x_{i}+\Delta x\right) \beta_{x}+\boldsymbol{w}_{i}{ }^{\prime} \boldsymbol{\beta}_{w}\right)-P\left(x_{i} \beta_{x}+\boldsymbol{w}_{i}{ }^{\prime} \boldsymbol{\beta}_{w}\right)}{\Delta x}\right)$.

Empirically, this can be understood as the difference in predicted values for the observed $y$-value and a small increase in the $x$-value for each observation, divided by the small increase $(\Delta x)$. The average of this difference in predictions over all observations gives then the AME. Semi-elasticities for continuous variables are calculated with the formula

$$
e P(y=1 \mid x, \boldsymbol{w}) / d x=E\left(\frac{d P_{i} / d x_{i}}{P_{i 0}}\right)
$$

wherein the aforementioned individual marginal effect is again divided by the individual 'base level' $\left(P_{i 0}\right) . P_{i 0}$ is calculated as the predicted probabilities of each individual with the observed $x$-values. The average yields semi-elasticities, representing a relative change in the predicted probability of $P$ with a small increase in $x$. For categorical variables, although the Stata's default ${ }^{1}$ proposes otherwise, we consider interpreting changes in relation to the reference category is more intuitive. Therefore, we divide the marginal effect by the predictive margins for the reference category in a similar fashion as done for continuous variables.

For the calculation of heterogeneous effects, e.g. by gender and region, the values of gender and region are held fixed for all observations in the calculation of the predicted probabilities. AME and semi-elasticities are then derived as described in this section.

A methodological problem is that sample members with specific characteristics, such as a high level of educational attainment or unobserved characteristics that are favourable for employment opportunities, may leave welfare receipt or unemployment very quickly. These sample members are unlikely to be assigned to ALMP programmes simply because they are not available as welfare benefit recipients long enough to be assigned to ALMP programmes. In principle, however, we are interested in each sample

1 Stata's default setting calculates semi-elasticities for categorical variables as log differences in the predicted values for the reference category and the respective category of interest. 
member's ALMP programme participation probability during a six-month time window had they been available for this duration of time.

In order to deal with this problem, we excluded non-participants from the sample who did not have the chance to participate in an ALMP programme due to their short duration of unemployment and welfare receipt. This was done using a procedure very similar to that applied in ALMP programme evaluation studies based on matching methods, such as Hohmeyer und Wolff (2012) or Harrer et al. (2020). Details of the sample adjustment procedure are as follows: sample members who did not participate in a given ALMP programme during the six-month time window are randomly assigned a fictional programme start date on the basis of the distribution of actual programme start dates for that ALMP programme in the sample. The distribution of programme start dates is derived from Kaplan-Meier estimates of the time until ALMP programme entry for the full sample. Non-participants are then excluded from the sample if they left welfare receipt or unemployment before the time of their randomly assigned fictional programme start date. Participants are excluded if they temporarily exited benefit receipt or were temporarily employed before their actual programme start, since they do not consistently fulfil the sample definition.

As the distribution of ALMP programme start dates is different for each programme we analyse, a different number of non-participants is excluded each time, and thus the sample size varies across the models we estimate for participation in each type of programme. $^{2}$ At the end, people included in or excluded from one model can appear in another one, no matter if they are treated or not.

2 As we estimate effects separately for each measure analysed with separate samples, AME may not only differ due to the estimated coefficients, but also due to differences in the distribution of covariates in each sample. However, the covariate values among the nontreated observations are very similar, as can be seen in table 1 . Therefore, we deem it possible to compare effect estimations of AME across the estimated models. 
Appendix B Sample Descriptives

B.1 Absolute number and relative share of sample members with welfare receipt and employment experience when aged 14 to 18 in years

\begin{tabular}{lll}
\hline & $N$ & Mean \\
\hline Welfare receipt 14-18: None & 23,448 & 0.348 \\
Welfare receipt 14-18: >0 to 1 years & 6,011 & 0.089 \\
Welfare receipt 14-18: >1 to 2 years & 5,211 & 0.077 \\
Welfare receipt 14-18: >2 to 3 years & 5,796 & 0.086 \\
Welfare receipt 14-18: >3 to 4 years & 26,944 & 0.400 \\
Employment experience 14-18: None & 39,681 & 0.589 \\
Employment experience 14-18: >0 to 1 years & 23,003 & 0.341 \\
Employment experience 14-18: >1 to 2 years & 3,677 & 0.055 \\
Employment experience 14-18: >2 to 3 years & 879 & 0.013 \\
Employment experience 14-18: >3 to 4 years & 170 & 0.003 \\
Total number of observations & 67,410 & \\
\hline
\end{tabular}

B.2 Absolute number and relative share of treated, controls and excluded due to random program start by programme

\begin{tabular}{lll}
\hline & $N$ & Mean \\
\hline One-Euro-Jobs: Control & 48,874 & 0.725 \\
One-Euro-Jobs: Treated & 1,638 & 0.024 \\
One-Euro-Jobs: Excluded & 16,898 & 0.251 \\
Outsourced measures: Control & 43,542 & 0.646 \\
Outsourced measures: Treated & 8,202 & 0.122 \\
Outsourced measures: Excluded & 15,666 & 0.232 \\
In-firm training: Control & 50,721 & $0.75^{2}$ \\
In-firm training: Treated & 1,501 & 0.022 \\
In-firm training: Excluded & 15,188 & 0.225 \\
Wage subsidies: Control & 51,068 & 0.758 \\
Wage subsidies: Treated & 566 & 0.008 \\
Wage subsidies: Excluded & 15,776 & 0.234 \\
\hline
\end{tabular}


B.3 Absolute number, mean and standard deviation for control variables included in the model estimation for the full sample

\begin{tabular}{|c|c|c|c|}
\hline & $N$ & Mean & S.D. \\
\hline Female & 31,683 & 0.470 & 0.499 \\
\hline Age: 20 & 21,377 & 0.317 & 0.465 \\
\hline Age: 21 & 22,487 & 0.334 & 0.471 \\
\hline Age: 22 & 23,546 & 0.349 & 0.477 \\
\hline German nationality: Foreign nationality & 15,582 & 0.231 & 0.422 \\
\hline German nationality: German nationality & 51,624 & 0.766 & 0.423 \\
\hline German nationality: Missing & 204 & 0.003 & 0.055 \\
\hline Disabled person: Not disabled & 65,036 & 0.965 & 0.184 \\
\hline Disabled person: Disabled & 1,300 & 0.019 & 0.138 \\
\hline Disabled person: Missing & 1,074 & 0.016 & 0.125 \\
\hline Household: Single & 27,266 & 0.404 & 0.491 \\
\hline Household: With partner & 5,951 & 0.088 & 0.284 \\
\hline Household: With partner and children & 5,461 & 0.081 & 0.273 \\
\hline Household: Single parent & 4,332 & 0.064 & 0.245 \\
\hline Household: With one parent & $7,75^{1}$ & 0.115 & 0.319 \\
\hline Household: With two parents & 9,647 & 0.143 & $0.35^{\circ}$ \\
\hline Household: Other & 7,002 & 0.104 & 0.305 \\
\hline Marital status: Never married & 59,066 & 0.876 & 0.329 \\
\hline Marital status: Married & 3,974 & 0.059 & 0.236 \\
\hline $\begin{array}{l}\text { Marital status: Divorced/separated/ } \\
\text { widowed }\end{array}$ & $5^{21}$ & 0.008 & 0.088 \\
\hline Marital status: Missing & 3,849 & 0.057 & 0.232 \\
\hline Youngest child: No child under 11 & 57,647 & 0.855 & $0.35^{2}$ \\
\hline Youngest child: Child under 3 & 6,365 & 0.094 & 0.292 \\
\hline Youngest child: Child aged 3-10 & 3,398 & 0.050 & 0.219 \\
\hline Number of siblings & & 0.314 & 0.812 \\
\hline $\begin{array}{l}\text { Duration of welfare receipt in last two years } \\
\text { (in days) }\end{array}$ & & 501.957 & 240.635 \\
\hline $\begin{array}{l}\text { Duration in minor employment in last } \\
8 \text { years: None }\end{array}$ & 39,097 & 0.580 & 0.494 \\
\hline $\begin{array}{l}\text { Duration in minor employment in last } \\
8 \text { years: } 1-9 \text { o days }\end{array}$ & 10,700 & 0.159 & 0.365 \\
\hline $\begin{array}{l}\text { Duration in minor employment in last } \\
8 \text { years: } 91-182 \text { days }\end{array}$ & 6,36 o & 0.094 & 0.292 \\
\hline $\begin{array}{l}\text { Duration in minor employment in last } \\
8 \text { years: } 183-364 \text { days }\end{array}$ & 5,800 & 0.086 & 0.280 \\
\hline $\begin{array}{l}\text { Duration in minor employment in last } \\
8 \text { years: } 365^{-729} \text { days }\end{array}$ & 3,874 & 0.057 & 0.233 \\
\hline
\end{tabular}


B.3 Absolute number, mean and standard deviation for control variables included in the model estimation for the full sample (cont.)

\begin{tabular}{|c|c|c|c|}
\hline & $N$ & Mean & S.D. \\
\hline Duration in minor employment in last & 1,579 & 0.023 & 0.151 \\
\hline \multicolumn{4}{|l|}{8 years: $>=73$ o days } \\
\hline Duration in vocational training in last & 45,691 & 0.678 & 0.467 \\
\hline \multicolumn{4}{|l|}{8 years: None } \\
\hline Duration in vocational training in last & 3,418 & 0.051 & 0.219 \\
\hline \multicolumn{4}{|l|}{8 years: $1-90$ days } \\
\hline Duration in vocational training in last & 3,312 & 0.049 & 0.216 \\
\hline \multicolumn{4}{|l|}{8 years: $91-182$ days } \\
\hline Duration in vocational training in last & 3,739 & 0.055 & 0.229 \\
\hline \multicolumn{4}{|l|}{8 years: $183-364$ days } \\
\hline Duration in vocational training in last & $11,25^{\circ}$ & 0.167 & 0.373 \\
\hline \multicolumn{4}{|l|}{8 years: $>=365$ days } \\
\hline Employment status: Unemployed/sick & 51,293 & 0.761 & 0.427 \\
\hline Employment status: Employed/job seeker & 16,117 & 0.239 & 0.427 \\
\hline No partner & 55,998 & 0.831 & 0.375 \\
\hline Age of partner: $<22$ & 3,454 & 0.051 & 0.220 \\
\hline Age of partner: $22-24$ & 3,368 & $0.05^{\circ}$ & 0.218 \\
\hline Age of partner: $25^{-27}$ & 2,220 & 0.033 & 0.178 \\
\hline Age of partner: $>=28$ & 2,370 & 0.035 & 0.184 \\
\hline Partner's nationality: German nationality & 8,516 & 0.126 & 0.332 \\
\hline Partner's nationality: Foreign nationality & 2,896 & 0.043 & 0.203 \\
\hline \multicolumn{3}{|l|}{ degree } & 0.325 \\
\hline Partner's vocational degree: Vocational degree & 2,580 & 0.038 & 0.192 \\
\hline \multicolumn{3}{|l|}{ (incl. Ph.D.) } & 0.046 \\
\hline Partner's vocational degree: Missing & 597 & 0.009 & 0.094 \\
\hline Partner's employment: No job & 8,146 & 0.121 & 0.326 \\
\hline Partner's employment: Contributory job & 1,896 & 0.028 & 0.165 \\
\hline Partner's employment: Apprenticeship & 489 & 0.007 & 0.085 \\
\hline Partner's employment: Minijob & 881 & 0.013 & 0.114 \\
\hline Partner's employment duration in last 8 years: & 4,839 & 0.072 & $0.25^{8}$ \\
\hline \multicolumn{4}{|l|}{ None } \\
\hline Partner's employment duration in last & 2,279 & 0.034 & 0.181 \\
\hline \multicolumn{4}{|l|}{8 years: $1-182$ days } \\
\hline Partner's employment duration in last & 1,174 & 0.017 & 0.131 \\
\hline 8 years: $183-364$ days & & & \\
\hline
\end{tabular}


B.3 Absolute number, mean and standard deviation for control variables included in the model estimation for the full sample (cont.)

\begin{tabular}{|c|c|c|c|}
\hline & $N$ & Mean & S.D. \\
\hline $\begin{array}{l}\text { Partner's employment duration in last } \\
8 \text { years: } 365^{-729} \text { days }\end{array}$ & 1,466 & 0.022 & 0.146 \\
\hline $\begin{array}{l}\text { Partner's employment duration in last } \\
8 \text { years: }>=73 \text { o days }\end{array}$ & 1,654 & 0.025 & 0.155 \\
\hline $\begin{array}{l}\text { Partner's minor employment duration } \\
\text { in last } 8 \text { years: None }\end{array}$ & 5,596 & 0.083 & 0.276 \\
\hline $\begin{array}{l}\text { Partner's minor employment duration } \\
\text { in last } 8 \text { years: } 1-182 \text { days }\end{array}$ & 2,872 & 0.043 & 0.202 \\
\hline $\begin{array}{l}\text { Partner's minor employment duration } \\
\text { in last } 8 \text { years: } 183-364 \text { days }\end{array}$ & 1,207 & 0.018 & 0.133 \\
\hline $\begin{array}{l}\text { Partner's minor employment duration in last } \\
8 \text { years: } 365^{-729} \text { days }\end{array}$ & 1,737 & 0.026 & $0.15^{8}$ \\
\hline $\begin{array}{l}\text { Partner's vocational training duration in last } \\
8 \text { years: None }\end{array}$ & 7,638 & 0.113 & 0.317 \\
\hline $\begin{array}{l}\text { Partner's vocational training duration in last } \\
8 \text { years: } 1-364 \text { days }\end{array}$ & 1,312 & 0.019 & 0.138 \\
\hline $\begin{array}{l}\text { Partner's vocational training duration in last } \\
8 \text { years: }>=365 \text { days }\end{array}$ & 2,462 & 0.037 & 0.188 \\
\hline $\begin{array}{l}\text { Partner's welfare receipt duration in last } \\
9 \text { years: None }\end{array}$ & 2,414 & 0.036 & 0.186 \\
\hline $\begin{array}{l}\text { Partner's welfare receipt duration in last } \\
9 \text { years: } 1-364 \text { days }\end{array}$ & 2,695 & 0.040 & 0.196 \\
\hline $\begin{array}{l}\text { Partner's welfare receipt duration in last } \\
9 \text { years: } 465^{-1095} \text { days }\end{array}$ & 2,708 & 0.040 & 0.196 \\
\hline $\begin{array}{l}\text { Partner's welfare receipt duration in last } \\
9 \text { years: } 1096-2191 \text { days }\end{array}$ & 3,595 & 0.053 & 0.225 \\
\hline Unemployment rate (in \%) & & $9 \cdot 5^{22}$ & 3.219 \\
\hline Long-term unemployment rate (in \%) & & $3 \cdot 753$ & 1.599 \\
\hline $\begin{array}{l}\text { Unemployment rate of welfare recipients } \\
\text { (in \%) }\end{array}$ & & 6.994 & 2.963 \\
\hline Vacancy-unemployment ratio & & 0.159 & 0.081 \\
\hline Regional information missing & 128 & 0.002 & 0.044 \\
\hline East Germany (incl. Berlin) & 19,387 & 0.288 & 0.453 \\
\hline Jobcenter inflow rate to sanctions $($ age $<25)$ & & 2.998 & $1.5^{26}$ \\
\hline
\end{tabular}


B.3 Absolute number, mean and standard deviation for control variables included in the model estimation for the full sample (cont.)

\begin{tabular}{|c|c|c|c|}
\hline & $N$ & Mean & S.D. \\
\hline $\begin{array}{l}\text { Jobcenter inflow rate to One-Euro-Jobs } \\
(\text { age }<25)\end{array}$ & & 0.301 & 0.405 \\
\hline $\begin{array}{l}\text { Jobcenter inflow rate to outsourced measures } \\
(\text { age }<25)\end{array}$ & & 1.906 & 1.373 \\
\hline $\begin{array}{l}\text { Jobcenter inflow rate to in-firm training } \\
(\text { age }<25)\end{array}$ & & 0.429 & 0.375 \\
\hline Jobcenter information missing & $25^{2}$ & 0.004 & 0.061 \\
\hline Total number of observations & 67,410 & & \\
\hline
\end{tabular}




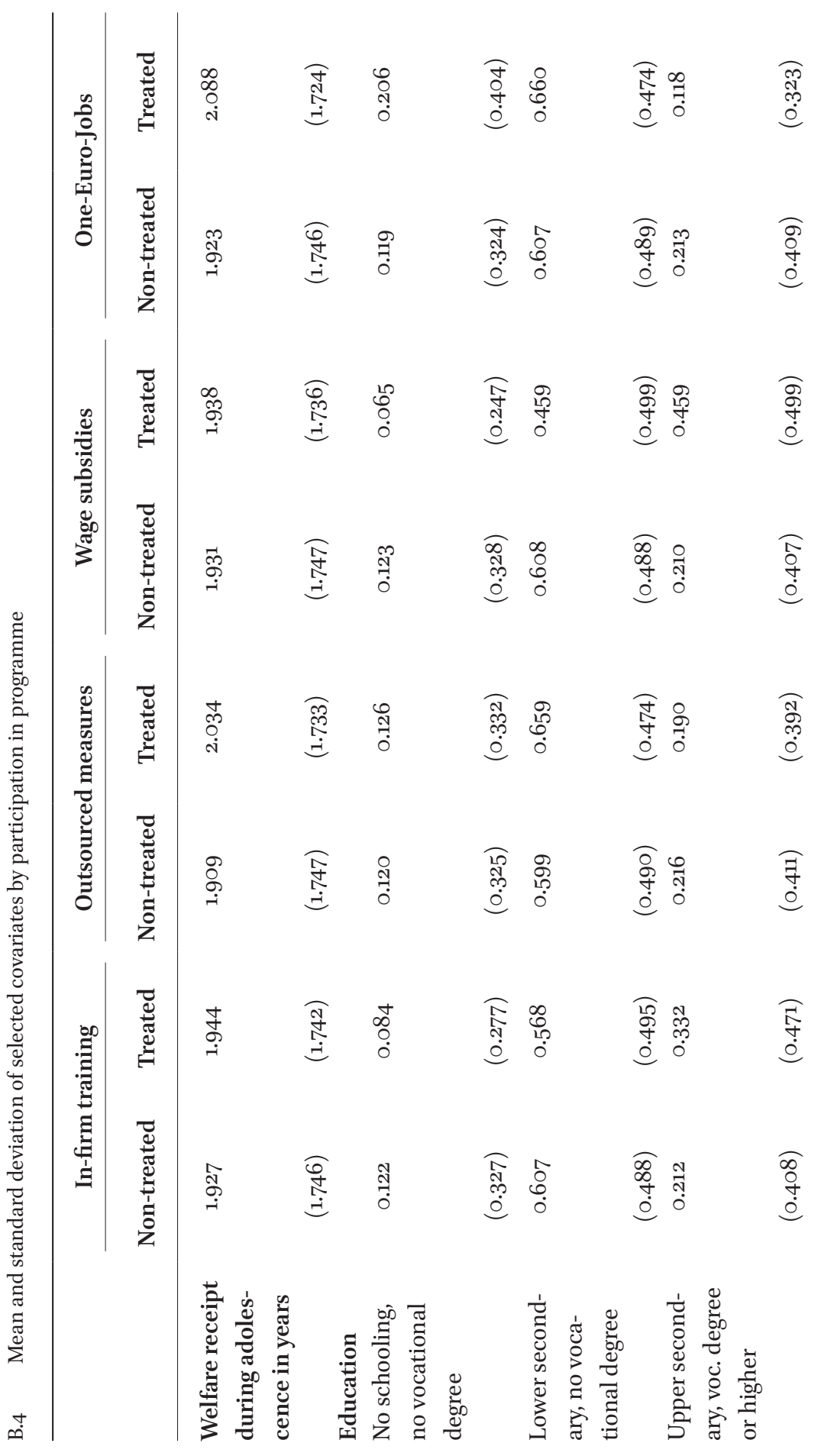




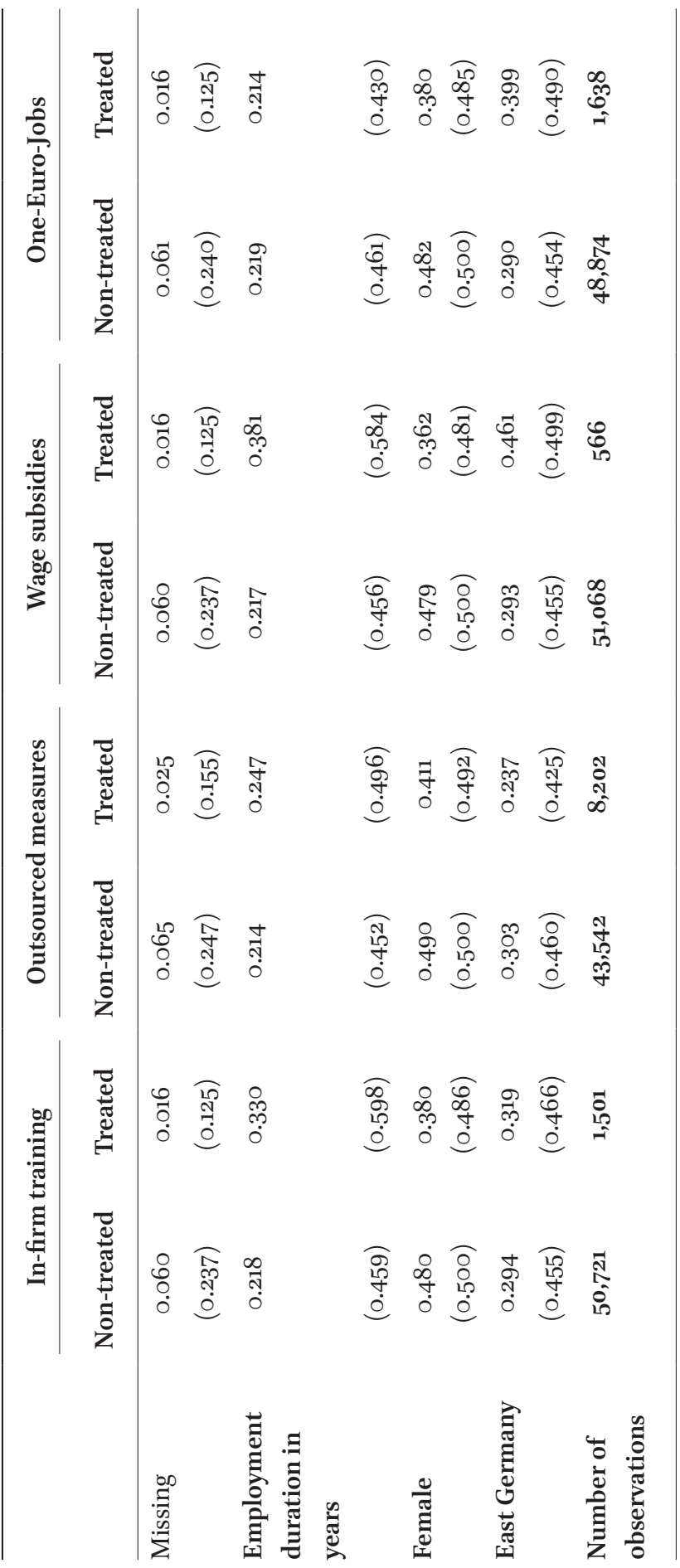


Appendix C Logistic regression of programme participation on welfare receipt, education, employment duration and further control variables (Standard errors in parentheses)

\begin{tabular}{|c|c|c|c|c|}
\hline & $\begin{array}{l}\text { In-firm } \\
\text { training }\end{array}$ & $\begin{array}{l}\text { Outsourced } \\
\text { measures }\end{array}$ & $\begin{array}{l}\text { Wage } \\
\text { subsidies }\end{array}$ & One-Euro-Jobs \\
\hline $\begin{array}{l}\text { Welfare receipt in years } \\
\left(\text { age } 14^{-18)}\right.\end{array}$ & 0.0182 & $0.0215^{* *}$ & $(0.0277)$ & (o.0169) \\
\hline \multicolumn{5}{|l|}{$\begin{array}{l}\text { Educational level } \\
\text { (Ref: No schooling, no } \\
\text { vocational degree) }\end{array}$} \\
\hline $\begin{array}{l}\text { Lower secondary without } \\
\text { vocational degree }\end{array}$ & $\begin{array}{l}0.294^{* *} \\
(0.0996)\end{array}$ & $\begin{array}{l}\text { o.o696 } \\
(0.0389)\end{array}$ & $\begin{array}{l}0.219 \\
(0.180)\end{array}$ & $\begin{array}{l}-0.419^{* * *} \\
(0.0681)\end{array}$ \\
\hline $\begin{array}{l}\text { Upper secondary, voca- } \\
\text { tional degree or higher }\end{array}$ & $\begin{array}{l}0.713^{* * *} \\
(0.108)\end{array}$ & $\begin{array}{l}-0.130^{* *} \\
(0.0472)\end{array}$ & $\begin{array}{l}0.974^{* * *} \\
(0.187)\end{array}$ & $\begin{array}{l}-0.995^{* * *} \\
(0.0992)\end{array}$ \\
\hline Missing & $\begin{array}{l}-0.207 \\
(0.233)\end{array}$ & $\begin{array}{l}-0.530^{* * *} \\
(0.0859)\end{array}$ & $\begin{array}{l}0.00617 \\
(0.392)\end{array}$ & $\begin{array}{l}-1.020^{* * *} \\
(0.214)\end{array}$ \\
\hline $\begin{array}{l}\text { Employment duration in } \\
\text { years }\end{array}$ & $\begin{array}{l}0.262^{* * *} \\
(0.0487)\end{array}$ & $0.123^{* * *}$ & $\begin{array}{l}0.383^{* * *} \\
(0.0727)\end{array}$ & $\begin{array}{l}0.0323 \\
(0.0612)\end{array}$ \\
\hline Female & $\begin{array}{l}-0.341^{* * *} \\
(0.0611)\end{array}$ & $\begin{array}{l}-0.198^{* * *} \\
(0.0279)\end{array}$ & $\begin{array}{l}-0.33^{* * *} \\
(0.0972)\end{array}$ & $\begin{array}{l}-0.225^{* * *} \\
(0.0585)\end{array}$ \\
\hline \multicolumn{5}{|l|}{$\begin{array}{l}\text { Children in household } \\
\text { (Ref: No child < } 11 \text { years) }\end{array}$} \\
\hline Youngest child $<3$ years & $\begin{array}{l}-0.854 \\
(0.755)\end{array}$ & $\begin{array}{l}-0.0665 \\
(0.493)\end{array}$ & $\begin{array}{l}0.95^{2} \\
(1.469)\end{array}$ & $\begin{array}{l}-0.0967 \\
(0.941)\end{array}$ \\
\hline Youngest child aged $3-10$ & $\begin{array}{l}-0.9 \circ 6 \\
(0.8 \circ 6)\end{array}$ & $\begin{array}{l}0.233 \\
(0.508)\end{array}$ & $\begin{array}{l}1.604 \\
(1.472)\end{array}$ & $\begin{array}{l}-0.309 \\
(0.983)\end{array}$ \\
\hline \multicolumn{5}{|l|}{$\begin{array}{l}\text { Female * Children in } \\
\text { household }\end{array}$} \\
\hline \multirow[t]{2}{*}{$\begin{array}{l}\text { Female * Youngest child } \\
<3 \text { years }\end{array}$} & -0.332 & $-0.515^{* * *}$ & $-0.970^{*}$ & $-1.003^{* * *}$ \\
\hline & $(0.263)$ & $(0.123)$ & $(0.434)$ & $(0.284)$ \\
\hline $\begin{array}{l}\text { Female * Youngest child } \\
\text { aged } 3^{-10}\end{array}$ & $\begin{array}{l}-0.346 \\
(0.403)\end{array}$ & $-0.459^{* *}$ & $\begin{array}{l}-1.261^{*} \\
(0.565)\end{array}$ & $(0.404)$ \\
\hline Age & 0.0155 & -0.0100 & -0.00898 & 0.00854 \\
\hline
\end{tabular}


Logistic regression with dependent variables programme participation (cont.)

\begin{tabular}{|c|c|c|c|c|}
\hline & $\begin{array}{l}\text { In-firm } \\
\text { training }\end{array}$ & $\begin{array}{l}\text { Outsourced } \\
\text { measures }\end{array}$ & $\begin{array}{l}\text { Wage } \\
\text { subsidies }\end{array}$ & One-Euro-Jobs \\
\hline & $(0.0347)$ & $(0.0159)$ & $(0.0568)$ & $(0.0328)$ \\
\hline \multicolumn{5}{|l|}{$\begin{array}{l}\text { Nationality (Ref: Foreign } \\
\text { nationality) }\end{array}$} \\
\hline German nationality & $\begin{array}{l}0.0799 \\
(0.0818)\end{array}$ & $\begin{array}{l}0.241^{* * *} \\
(0.0356)\end{array}$ & $\begin{array}{l}0.245 \\
(0.147)\end{array}$ & $\begin{array}{l}0.661^{* * *} \\
(0.0910)\end{array}$ \\
\hline Missing & $\begin{array}{l}0.707 \\
(0.427)\end{array}$ & $\begin{array}{l}0.209 \\
(0.232)\end{array}$ & $\begin{array}{l}0.0517 \\
(1.015)\end{array}$ & $\begin{array}{l}-0.250 \\
(0.720)\end{array}$ \\
\hline \multicolumn{5}{|l|}{ Disability status (Ref: } \\
\hline Disabled & $\begin{array}{l}0.246 \\
(0.166)\end{array}$ & $\begin{array}{l}-0.380 * * * \\
(0.0941)\end{array}$ & $\begin{array}{l}-1.559^{* *} \\
(0.583)\end{array}$ & $\begin{array}{l}0.422^{* *} \\
(0.134)\end{array}$ \\
\hline Missing & $\begin{array}{l}-0.863^{*} \\
(0.422)\end{array}$ & $\begin{array}{l}-0.479^{* *} \\
(0.150)\end{array}$ & $\begin{array}{l}0.433 \\
(0.402)\end{array}$ & $\begin{array}{l}-0.487 \\
(0.421)\end{array}$ \\
\hline \multicolumn{2}{|l|}{ Household status (Ref: } & & & \\
\hline With partner & $\begin{array}{l}0.0697 \\
(0.230)\end{array}$ & $\begin{array}{l}-0.138 \\
(0.115)\end{array}$ & $\begin{array}{l}-0.189 \\
(0.367)\end{array}$ & $\begin{array}{l}0.0185 \\
(0.264)\end{array}$ \\
\hline With partner and children & $\begin{array}{l}0.893 \\
(0.780)\end{array}$ & $\begin{array}{l}-0.075^{8} \\
(0.502)\end{array}$ & $\begin{array}{l}-0.818 \\
(1.501)\end{array}$ & $\begin{array}{l}-0.0306 \\
(0.970)\end{array}$ \\
\hline Single parent & $\begin{array}{l}1.054 \\
(0.771)\end{array}$ & $\begin{array}{l}0.181 \\
(0.496)\end{array}$ & $\begin{array}{l}-1.317 \\
(1.513)\end{array}$ & $\begin{array}{l}0.262 \\
(0.957)\end{array}$ \\
\hline With one parent & $\begin{array}{l}-0.0327 \\
(0.114)\end{array}$ & $\begin{array}{l}0.0200 \\
(0.0512)\end{array}$ & $\begin{array}{l}-0.309 \\
(0.203)\end{array}$ & $\begin{array}{l}-0.180 \\
(0.111)\end{array}$ \\
\hline With two parents & $\begin{array}{l}0.126 \\
(0.113)\end{array}$ & $\begin{array}{l}0.0235 \\
(0.0528)\end{array}$ & $\begin{array}{l}-0.103 \\
(0.194)\end{array}$ & $\begin{array}{l}-0.236^{*} \\
(0.116)\end{array}$ \\
\hline Other & $\begin{array}{l}-0.0289 \\
(0.0980)\end{array}$ & $\begin{array}{l}-0.05^{67} \\
(0.0445)\end{array}$ & $\begin{array}{l}-0.208 \\
(0.162)\end{array}$ & $\begin{array}{l}-0.368 * * \\
(0.0948)\end{array}$ \\
\hline \multicolumn{5}{|l|}{ Number of siblings } \\
\hline One sibling & $\begin{array}{l}-0.147 \\
(0.133)\end{array}$ & $\begin{array}{l}-0.136^{*} \\
(0.06 \circ 5)\end{array}$ & $\begin{array}{l}0.00461 \\
(0.229)\end{array}$ & $\begin{array}{l}-0.113 \\
(0.136)\end{array}$ \\
\hline Two siblings & $\begin{array}{l}-0.309 \\
(0.169)\end{array}$ & $\begin{array}{l}-0.0869 \\
(0.0711)\end{array}$ & $\begin{array}{l}-0.695^{*} \\
(0.353)\end{array}$ & $\begin{array}{l}-0.545^{* *} \\
(0.186)\end{array}$ \\
\hline Three siblings & $\begin{array}{l}-0.176 \\
(0.222)\end{array}$ & $\begin{array}{l}-0.157 \\
(0.0961)\end{array}$ & $\begin{array}{l}-0.369 \\
(0.440)\end{array}$ & $\begin{array}{l}-0.15^{2} \\
(0.220)\end{array}$ \\
\hline Four siblings & -0.135 & 0.00555 & -1.180 & -0.320 \\
\hline
\end{tabular}


Logistic regression with dependent variables programme participation (cont.)

\begin{tabular}{|c|c|c|c|c|}
\hline & $\begin{array}{l}\text { In-firm } \\
\text { training }\end{array}$ & $\begin{array}{l}\text { Outsourced } \\
\text { measures }\end{array}$ & $\begin{array}{l}\text { Wage } \\
\text { subsidies }\end{array}$ & One-Euro-Jobs \\
\hline & $(0.250)$ & $(0.102)$ & $(0.727)$ & $(0.263)$ \\
\hline \multicolumn{5}{|l|}{$\begin{array}{l}\text { Marital status (Ref: Never } \\
\text { married) }\end{array}$} \\
\hline Married & $\begin{array}{l}0.0715 \\
(0.16 \circ)\end{array}$ & $\begin{array}{l}-0.184^{*} \\
(0.0744)\end{array}$ & $\begin{array}{l}0.121 \\
(0.255)\end{array}$ & $\begin{array}{l}-0.15^{2} \\
(0.165)\end{array}$ \\
\hline \multirow[t]{2}{*}{$\begin{array}{l}\text { Divorced/separated/wid- } \\
\text { owed }\end{array}$} & 0.244 & -0.197 & 0.410 & -0.287 \\
\hline & $(0.300)$ & $\left(0.15^{\circ}\right)$ & $\left(0.5^{12}\right)$ & $(0.344)$ \\
\hline Missing & $\begin{array}{l}0.0645 \\
(0.135)\end{array}$ & $\begin{array}{l}-0.128 \\
(0.0668)\end{array}$ & $\begin{array}{l}0.0477 \\
(0.210)\end{array}$ & $\begin{array}{l}-0.209 \\
(0.139)\end{array}$ \\
\hline \multicolumn{5}{|c|}{ Age of partner $($ Ref: $<22)$} \\
\hline $22-24$ & $\begin{array}{l}-0.207 \\
(0.174)\end{array}$ & $\begin{array}{l}-0.108 \\
(0.0864)\end{array}$ & $\begin{array}{l}-0.325 \\
(0.270)\end{array}$ & $\begin{array}{l}0.278 \\
(0.178)\end{array}$ \\
\hline $25^{-27}$ & $\begin{array}{l}-0.460^{*} \\
(0.230)\end{array}$ & $\begin{array}{l}0.000760 \\
(0.102)\end{array}$ & $\begin{array}{l}-0.447 \\
(0.346)\end{array}$ & $\begin{array}{l}0.0287 \\
(0.230)\end{array}$ \\
\hline$>=28$ & $\begin{array}{l}-0.282 \\
(0.239)\end{array}$ & $\begin{array}{l}-0.100 \\
(0.112)\end{array}$ & $\begin{array}{l}-0.437 \\
(0.372)\end{array}$ & $\begin{array}{l}0.279 \\
(0.227)\end{array}$ \\
\hline $\begin{array}{l}\text { Partner's nationality: } \\
\text { foreign (Ref: German } \\
\text { nationality) } \\
\text { Partner's vocational } \\
\text { degree (Ref: None) }\end{array}$ & $\begin{array}{l}-0.344 \\
(0.216)\end{array}$ & $\begin{array}{l}-0.118 \\
(0.0925)\end{array}$ & $\begin{array}{l}-0.690 \\
(0.399)\end{array}$ & $\begin{array}{l}-0.882^{* *} \\
(0.268)\end{array}$ \\
\hline Vocational degree & $\begin{array}{l}0.110 \\
(0.187)\end{array}$ & $\begin{array}{l}-0.131 \\
(0.0958)\end{array}$ & $\begin{array}{l}0.300 \\
(0.278)\end{array}$ & $\begin{array}{l}0.126 \\
(0.195)\end{array}$ \\
\hline \multirow[t]{2}{*}{$\begin{array}{l}\text { University degree } \\
\text { (incl. Ph.D.) }\end{array}$} & 0.710 & -0.0300 & 0.782 & 0.255 \\
\hline & $(0.612)$ & $(0.361)$ & $(1.038)$ & $(0.742)$ \\
\hline Missing & $\begin{array}{l}-0.3^{26} \\
(0.354)\end{array}$ & $\begin{array}{l}0.175 \\
(0.136)\end{array}$ & $\begin{array}{l}-0.429 \\
(0.6 \circ 8)\end{array}$ & $\begin{array}{l}0.433 \\
(0.255)\end{array}$ \\
\hline \multicolumn{5}{|l|}{$\begin{array}{l}\text { Partner's employment } \\
\text { at sampling time point } \\
\text { (Ref: No job) }\end{array}$} \\
\hline Contributory job & $\begin{array}{l}0.425 \\
(0.228)\end{array}$ & $\begin{array}{l}-0.0165 \\
(0.115)\end{array}$ & $\begin{array}{l}-0.322 \\
(0.380)\end{array}$ & $\begin{array}{l}-0.377 \\
(0.309)\end{array}$ \\
\hline Apprenticeship & $\begin{array}{l}-0.193 \\
(0.393)\end{array}$ & $\begin{array}{l}-0.0805 \\
(0.190)\end{array}$ & $\begin{array}{l}0.337 \\
(0.514)\end{array}$ & $\begin{array}{l}0.275 \\
(0.400)\end{array}$ \\
\hline Mini job & 0.0648 & -0.140 & 0.135 & 0.297 \\
\hline
\end{tabular}


Logistic regression with dependent variables programme participation (cont.)

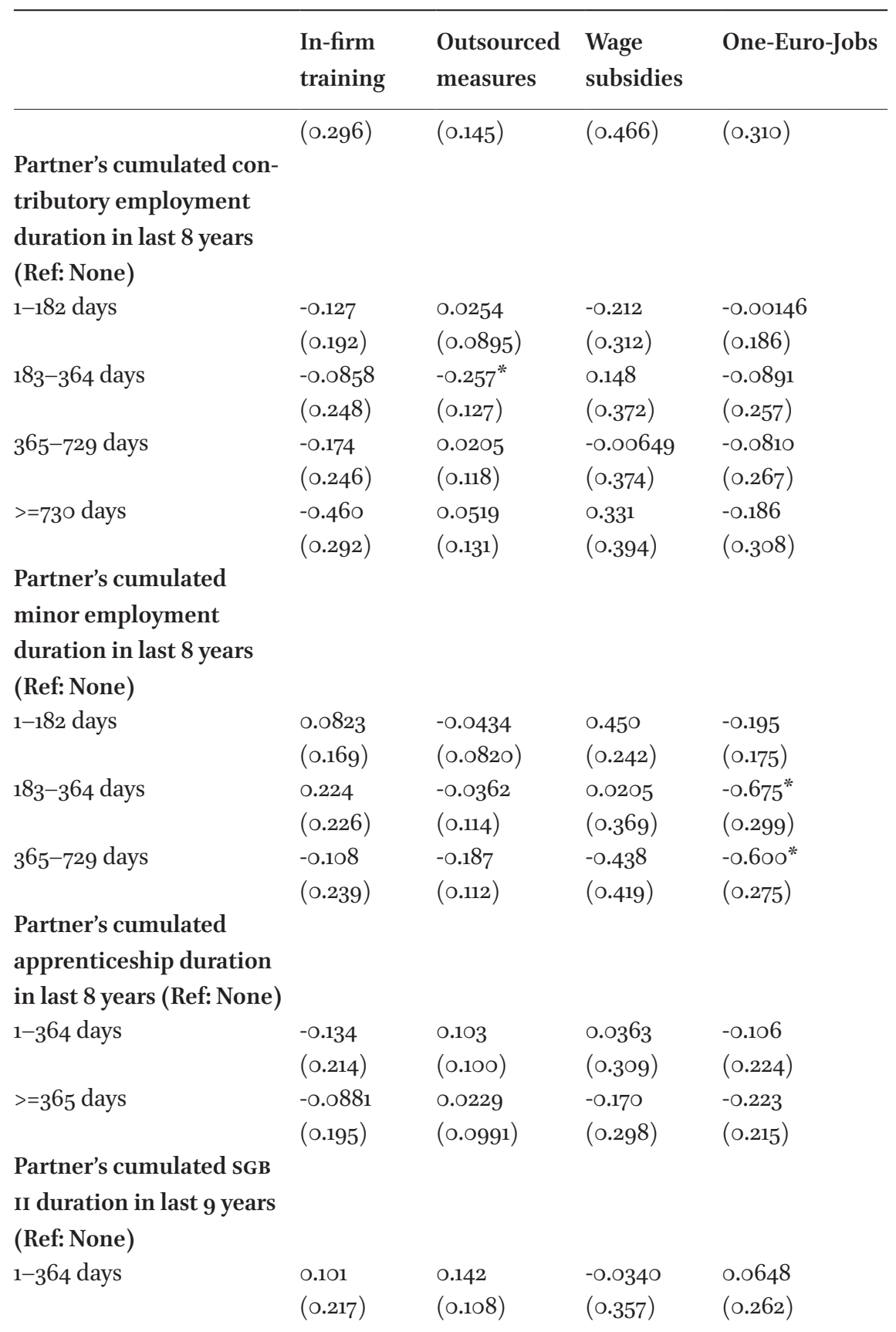


Logistic regression with dependent variables programme participation (cont.)

\begin{tabular}{|c|c|c|c|c|}
\hline & $\begin{array}{l}\text { In-firm } \\
\text { training }\end{array}$ & $\begin{array}{l}\text { Outsourced } \\
\text { measures }\end{array}$ & $\begin{array}{l}\text { Wage } \\
\text { subsidies }\end{array}$ & One-Euro-Jobs \\
\hline 465-1095 days & $\begin{array}{l}0.270 \\
(0.215)\end{array}$ & $\begin{array}{l}0.296 * * \\
(0.108)\end{array}$ & $\begin{array}{l}0.461 \\
(0.328)\end{array}$ & $\begin{array}{l}0.025^{2} \\
(0.261)\end{array}$ \\
\hline 1096-2191 days & $\begin{array}{l}0.00788 \\
(0.216)\end{array}$ & $\begin{array}{l}0.13^{2} \\
(0.106)\end{array}$ & $\begin{array}{l}\text { o.0519 } \\
(0.339)\end{array}$ & $\begin{array}{l}0.15^{1} \\
\left(0.25^{\circ}\right)\end{array}$ \\
\hline \multicolumn{5}{|l|}{$\begin{array}{l}\text { Cumulated minijob } \\
\text { duration in last } 8 \text { years } \\
\text { (Ref: None) }\end{array}$} \\
\hline 1-9o days & $\begin{array}{l}0.192^{* *} \\
(0.0737)\end{array}$ & $\begin{array}{l}-0.114^{* *} \\
(0.0352)\end{array}$ & $\begin{array}{l}0.0754 \\
(0.123)\end{array}$ & $\begin{array}{l}-0.0375 \\
(0.0707)\end{array}$ \\
\hline $91-182$ days & $\begin{array}{l}0.323^{* * *} \\
(0.0879)\end{array}$ & $\begin{array}{l}-0.0843 \\
(0.0441)\end{array}$ & $\begin{array}{l}0.434^{* *} \\
(0.137)\end{array}$ & $\begin{array}{l}-0.218^{*} \\
(0.0998)\end{array}$ \\
\hline $183-364$ days & $\begin{array}{l}0.177 \\
(0.0978)\end{array}$ & $\begin{array}{l}-0.155^{* *} \\
(0.0476)\end{array}$ & $\begin{array}{l}0.365^{*} \\
(0.147)\end{array}$ & $\begin{array}{l}-0.262 * \\
(0.108)\end{array}$ \\
\hline $365-729$ days & $\begin{array}{l}0.292^{* *} \\
(0.113)\end{array}$ & $\begin{array}{l}-0.176^{* *} \\
(0.0586)\end{array}$ & $\begin{array}{l}0.207 \\
(0.192)\end{array}$ & $\begin{array}{l}-0.202 \\
(0.135)\end{array}$ \\
\hline$>=73$ o days & $\begin{array}{l}0.411 * \\
(0.162)\end{array}$ & $\begin{array}{l}-0.115 \\
(0.0906)\end{array}$ & $\begin{array}{l}0.139 \\
(0.290)\end{array}$ & $\begin{array}{l}-0.851^{* *} \\
(0.294)\end{array}$ \\
\hline \multicolumn{5}{|l|}{$\begin{array}{l}\text { Cumulated apprentice- } \\
\text { ship in last } 8 \text { years } \\
\text { (Ref: None) }\end{array}$} \\
\hline 1-9o days & $\begin{array}{l}0.0894 \\
(0.124)\end{array}$ & $\begin{array}{l}-0.101 \\
(0.0583)\end{array}$ & $\begin{array}{l}0.498^{* *} \\
(0.193)\end{array}$ & $\begin{array}{l}0.0360 \\
(0.112)\end{array}$ \\
\hline $91-182$ days & $\begin{array}{l}0.15^{1} \\
(0.122)\end{array}$ & $\begin{array}{l}-0.0644 \\
(0.0586)\end{array}$ & $\begin{array}{l}0.3^{21} \\
(0.208)\end{array}$ & $\begin{array}{l}0.0193 \\
(0.117)\end{array}$ \\
\hline $183-364$ days & $\begin{array}{l}0.312^{* *} \\
(0.109)\end{array}$ & $\begin{array}{l}0.00427 \\
(0.0541)\end{array}$ & $\begin{array}{l}0.207 \\
(0.208)\end{array}$ & $\begin{array}{l}0.0192 \\
(0.109)\end{array}$ \\
\hline$>=365$ days & $\begin{array}{l}0.498^{* * *} \\
(0.0706)\end{array}$ & $\begin{array}{l}0.172^{* * *} \\
(0.0371)\end{array}$ & $\begin{array}{l}0.908^{* * *} \\
(0.109)\end{array}$ & $\begin{array}{l}-0.104 \\
(0.0853)\end{array}$ \\
\hline $\begin{array}{l}\text { Duration in SGB II two } \\
\text { years ago to sampling date }\end{array}$ & $\begin{array}{l}-0.000102 \\
(0.000131)\end{array}$ & $\begin{array}{l}0.000110 \\
(0.0000631)\end{array}$ & $\begin{array}{l}-0.000553^{* *} \\
(0.000206)\end{array}$ & $\begin{array}{l}0.000644^{* * *} \\
(0.000140)\end{array}$ \\
\hline $\begin{array}{l}\text { Non-employed job } \\
\text { seeker }^{3} \text { (Ref: Unemployed } \\
\text { jobseeker) }\end{array}$ & $\begin{array}{l}-0.609^{* * *} \\
(0.0831)\end{array}$ & $\begin{array}{l}-0.570^{* * *} \\
(0.0357)\end{array}$ & $\begin{array}{l}-0.507^{* * *} \\
(0.133)\end{array}$ & $\begin{array}{l}-0.453^{* * *} \\
(0.0768)\end{array}$ \\
\hline
\end{tabular}

3 People in this category are jobseekers who are not employed but also not registered as unemployed (for example, people who due to childcare responsibilities are currently not available), but are already looking for a job. 
Logistic regression with dependent variables programme participation (cont.)

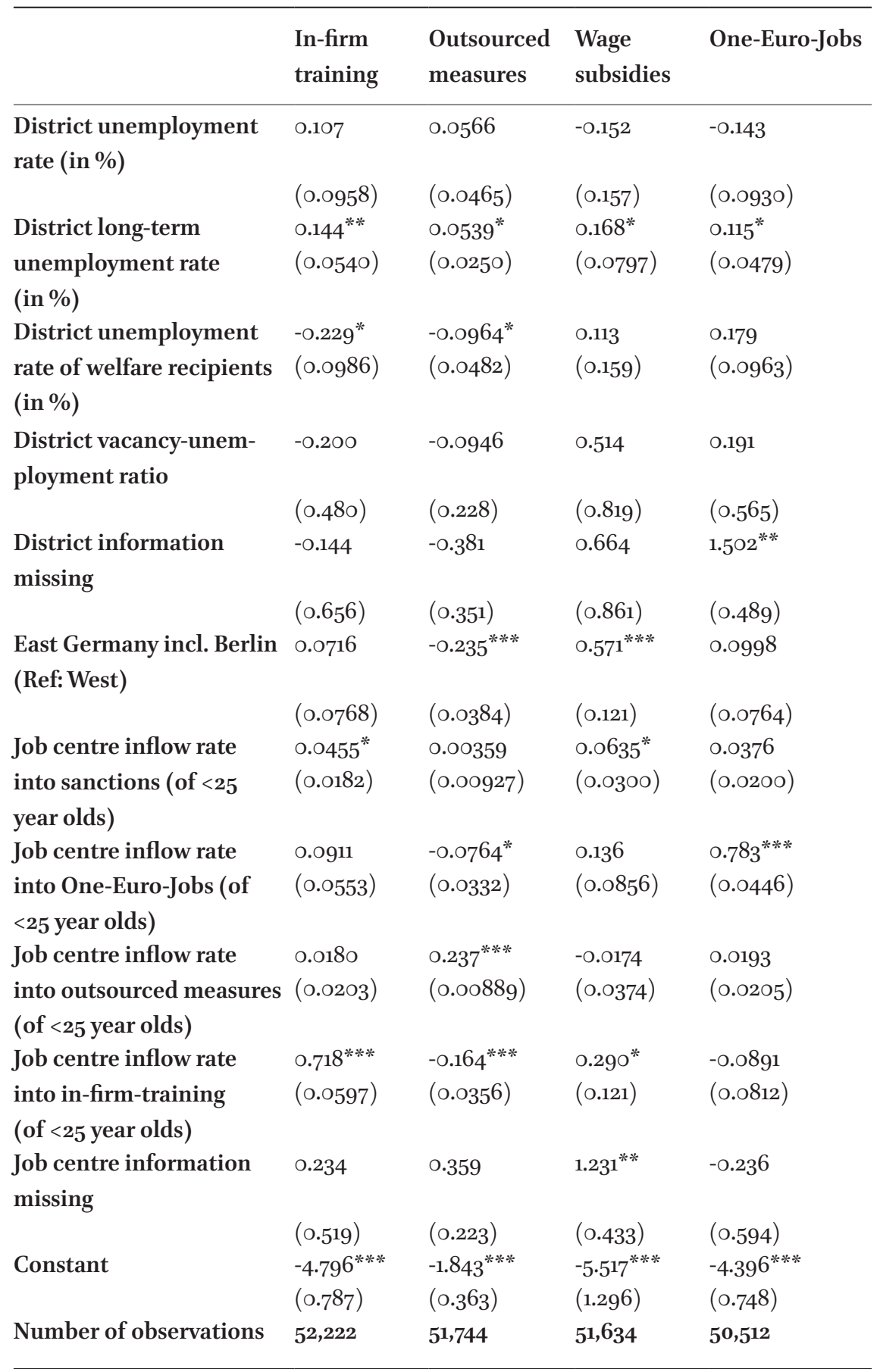


Appendix D Effect Heterogeneity of Prior Welfare Experience

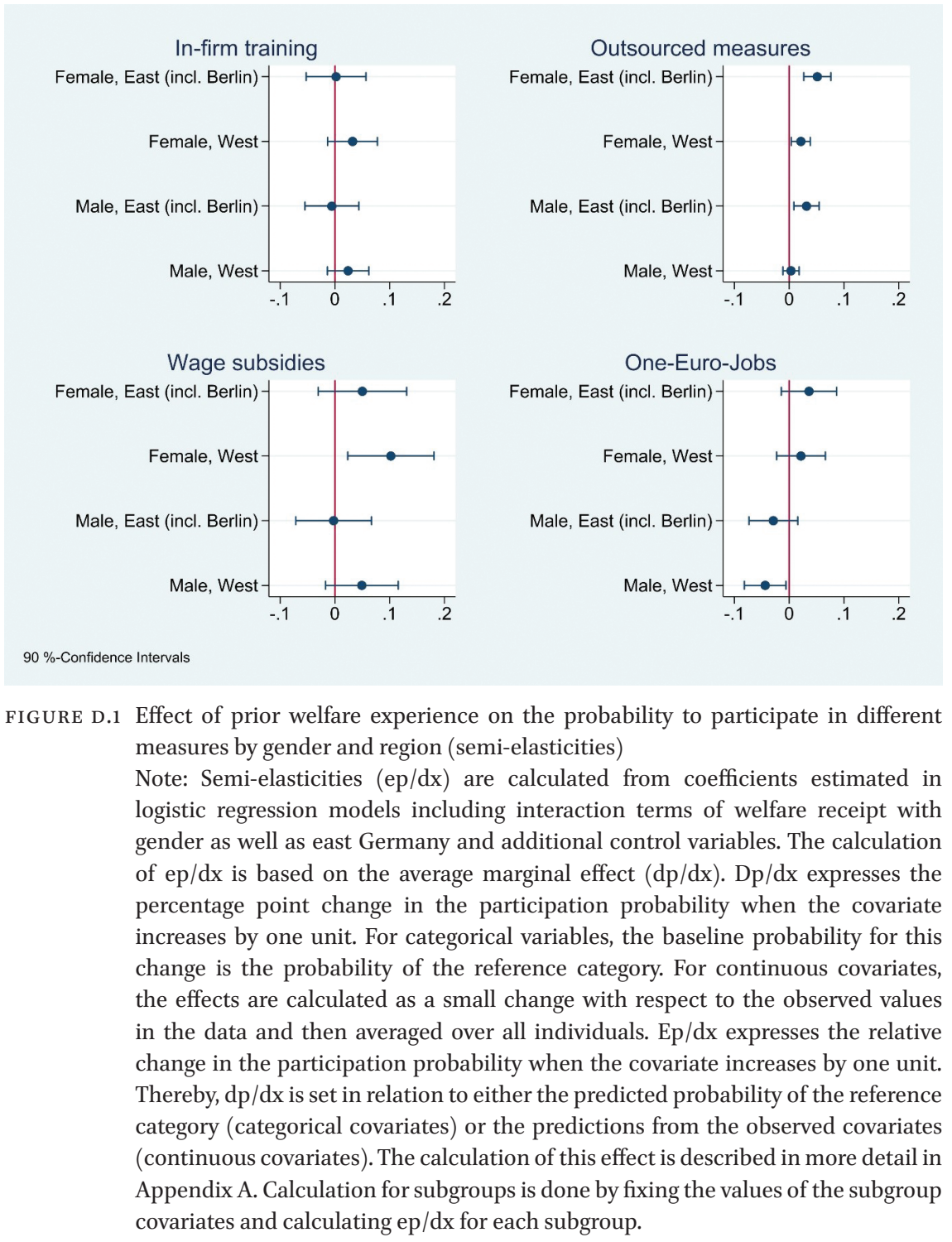


Appendix F Robustness Check with District-Clustered Standard Errors

TABLE F.1 Coefficients of main independent variables from logistic regression with districtclustered standard errors with dependent variables participation in programmes

(1)

$(2)$

(3)

$(4)$

\begin{tabular}{|c|c|c|c|c|}
\hline & $\begin{array}{l}\text { In-firm } \\
\text { training }\end{array}$ & $\begin{array}{l}\text { Outsourced } \\
\text { measures }\end{array}$ & $\begin{array}{c}\text { Wage } \\
\text { subsidies }\end{array}$ & $\begin{array}{l}\text { One-Euro- } \\
\text { Jobs }\end{array}$ \\
\hline \multirow{2}{*}{$\begin{array}{l}\text { Welfare receipt in years } \\
\text { (age 14-18) }\end{array}$} & 0.000384 & $0.00190^{+}$ & $0.000792^{* *}$ & -0.000131 \\
\hline & $(0.000500)$ & (0.00101) & (0.000280) & $(0.000675)$ \\
\hline \multirow{2}{*}{$\begin{array}{l}\text { Lower secondary without } \\
\text { vocational degree }\end{array}$} & $0.00589^{* *}$ & $0.0095^{+}$ & 0.000725 & $-0.0176^{* * *}$ \\
\hline & (0.00223) & (0.00574) & (0.00104) & (o.oo330) \\
\hline \multirow{2}{*}{$\begin{array}{l}\text { Upper secondary, vocational } \\
\text { degree or higher }\end{array}$} & $0.0196^{* * *}$ & $-0.017 \mathrm{O}^{* *}$ & $0.0121^{* * *}$ & $-0.0308 * * *$ \\
\hline & $(0.00343)$ & $(0.00636)$ & $(0.00174)$ & (o.oo339) \\
\hline \multirow{2}{*}{$\begin{array}{l}\text { Employment duration in } \\
\text { years }\end{array}$} & $0.00979 * * *$ & $0.0171^{* * *}$ & $0.00560^{* * *}$ & 0.000457 \\
\hline & $(0.00215)$ & (o.0o39o) & $(0.00136)$ & (o.oo161) \\
\hline Number of observations & $5^{2,222}$ & $5^{1,744}$ & $5^{1,634}$ & $5^{0,512}$ \\
\hline
\end{tabular}

